Anna Stepčenko

\title{
Sociālekonomiskā konteksta salīdzinošā analīze SEMPRE projekta spēcināšanas vietās
}

\author{
Comparative Analysis on the Socio-Economic \\ Context of the Local Empowerment Networks \\ in Rural Regions in SEMPRE Project ${ }^{1}$
}

\begin{abstract}
Summary
The comparative analysis of the socio-economic context includes the statistical data by the Eurostat on the purchasing power standards, density of population, change in population and comparison of these data between the local empowerment networks located in the eight Baltic sea region countries of the European Union. In addition to the statistical data there are analysed and compared data derived from a survey. The main issues in a questionnaire are related to the local empowerment networks' socio-economic specifics of the project partners. Other questions focus on the restricting factors that influence the life circumstances of the end-users and on the specific barriers and obstacles that social service providers face when working with the endusers. The factors which influence social service organizations' staff work conditions are divided in two groups - material and immaterial factors. The most restrictive factors due to social service organizations' staff are a large scale of the immaterial factors.
\end{abstract}

1 Latvijas Universitātei viens no projekta partnerības darba uzdevumiem bija sagatavot angḷu valodā sociālekonomiskā konteksta salīdzinošo analīzi SEMPRE projekta spēcināšanas vietās. Tāpēc tika uzrakstīti divi apjomīgi raksti. Viens raksts ir par vietu sociālekonomiskā konteksta salīdzinošo analīzi. Tā kā tika padziḷināti pētītas barjeras un šķēešlı̆i sociālo pakalpojumu organizāciju personāla darbā, tad otrajā rakstā ir analizēta šì izpēte. Abi raksti angḷ valodā ir ievietoti SEMPRE projekta elektroniskajā datubāzē (A. S.). 
Key words: purchasing power standard, density of population, change in population, factors influencing everyday life of the end-users, barriers and obstacles faced by the staff of social service provision organizations.

\section{Kopsavilkums}

Rakstā ir veikta projekta partneru izraudzìto sociālās spēcināšanas vietu sociālekonomiskā konteksta salīdzinošā analīze. Par vietu sociālekonomisko kontekstu ir divi informācijas avoti. Viens no tiem ir Eurostat statistiskie dati par pirktspējas standartiem, iedzīvotāju blīvumu un pārmaiṇām iedzīvotāju sastāvā šajās vietās. Otrs informācijas avots ir formalizēta partneru aptauja. Tajā ir iegūtas ziņas par vietu sociālekonomiskas specifikas raksturojumu, par ierobežojošiem faktoriem, kas ietekmē sociālo pakalpojumu galalietotāju dzīves apstākḷus. Cits jautājums ir par barjerām un šķēršliem, kas sastopami sociālo pakalpojumu organizāciju personāla darbā.

Atslēgvārdi: pirktspējas standarts, apdzīvotības blīvums, pārmaiṇas iedzīvotāju sastāvā, vietu sociālekonomiskā specifika, sociālo pakalpojumu galalietotāju dzīves apstākḷus ierobežojošie faktori, barjeras un šḳēršlı sociālo pakalpojumu organizāciju personāla darbā.

Tematika. Vietu pirktspējas standarta rādītāju salīdzinājums. Vietu apdzīvotības blīvuma rādītāju salīdzinājums. Vietu iedzīvotāju skaita pārmaiṇu rādītāju salīdzinājums. Lokālo spēcināšanas tīklu vietu sociālekonomiskās specifikas raksturojums. Sociālo pakalpojumu galalietotāju dzīves apstākḷus ietekmējošo faktoru raksturojums. Barjeras un šķēršşi sociālo pakalpojumu organizāciju darbā. Papildinformācija par barjerām un šḳēršliem sociālo pakalpojumu organizāciju darbā, kura balstīta uz padziḷinātas barjeru un šḳēršlı izpētes datiem, kas ir iegūti Latvijā, Somijā un Vācijā.

\section{Vietu sociālekonomiskā konteksta izziṇas metodologija}

Sociālo pakalpojumu organizāciju personāla darba pienākums ir ne tikai sniegt atbalstu un palīdzēt sociāli vājām un ievainojamām grupām tikt galā ar savu dzīves situāciju, bet arī mainīt sociālo pakalpojumu lietotāju domāšanas veidu un iesaistīt tos aktīvā rīcībā, lai labvēlīgi ietekmētu viņu dzīvi un viņi nebūtu tikai pasīvi pabalstu tērētāji. Šāda relatīvi inovatīva pieeja sociālo pakalpojumu sniegšanā palīdzības efektivitātes labad ir jābalsta uz daudzveidīgām zināšanām. Šim mērḳim daudzveidīgo zināšanu klāstā noder arī zināšanas par to vietu sociālekonomiskiem apstākḷiem, kur sociāli spēcināmās grupas dzīvo. 
Informācija par vietu sociālekonomisko kontekstu tika iegūta no diviem avotiem, lietojot divas informācijas ieguves metodes. Viena no tām ir kvantitatìvo statistisko datu analizzes metode, otra ir sociālo pakalpojumu organizāciju profesionāļu formalizēta elektroniska aptauja.

Projekta darba sākumā 2016. gada pirmajā pusē no Eurostat datubāzēm tika iegūta apjomā ierobežota interesējošā statistiskā informācija. Lìdztekus tika veikta formalizēta sociālo pakalpojumu organizāciju profesionāḷu aptauja. Aptaujā tika lūgts sniegt ìsas ziņas par trīs jautājumiem: par lokālās spēcināšanas tîkla vietu sociālekonomiskām īpatnībām, pakalpojumu galalietotāju dzīves apstākḷu novērtējumu un barjerām un šḳēešlı̆iem savā pakalpojumu sniedzēju darbā. Saṇemtās atbildes lielākoties bija lakoniskas, dažas - plaši izvērstas.

Statistiskie dati par reǵioniem, kuros ietilpst SEMPRE projektā iekḷautās lokālo spēcināšanas tīklu vietas, projekta sākumposmā Eurostat datu masīvā bija apkopoti un pieejami par 2013. gadu. Rādītāju skaits ir apzināti ierobežots ar trīs rādītājiem. Pirmais rādītājs ir pirktspējas standarts konkrētā reǵionā, kas skaitliski ir izteikts procentuāli, to salīdzinot ar Eiropas Savienības vidējo rādītāju. Otrais rādītājs ir reǵionu apdzīvotības blīvums un tā dinamika. Trešais rādītājs ir iedzīvotāju skaita pārmaiṇas reg̣ionā.

Statistisko datu salīdzinošã analīze tiek veikta nosaukto informatīvo tematu secībā, katru tematu beidzot ar secinājumiem. Salīdzinošās analīzes noslēgumā ir sniegti vispārināti secinājumi un daži ieteikumi.

\section{Statistisko datu salīdzinošã analīze}

\subsection{Pirktspējas standarta rādītāju salīdzinājums ${ }^{2}$ SEMPRE projekta vietās}

Sakārtojot pirktspējas standarta rādītāju rindu dilstošā secībā, partneri un valstis izkārtojas procentuāli lejupejošā kārtībā. Par

Avots: PPS/capita in \% of EU, 2013. Available: http://ec.europa.eu/eurostat/web/ regions/data/database. Izmantoti 2016. gada pirmajā pusē pieejamie Eurostat dati. 
pirktspējas standarta vidējo rādītāju Eiropas Savienībā ir pieņemts skaitlis 100 .

Projekta partneru sociālās spēcināšanas vietās pirktspējas rādītāji izkārtojas šādā dilstošā secībā:

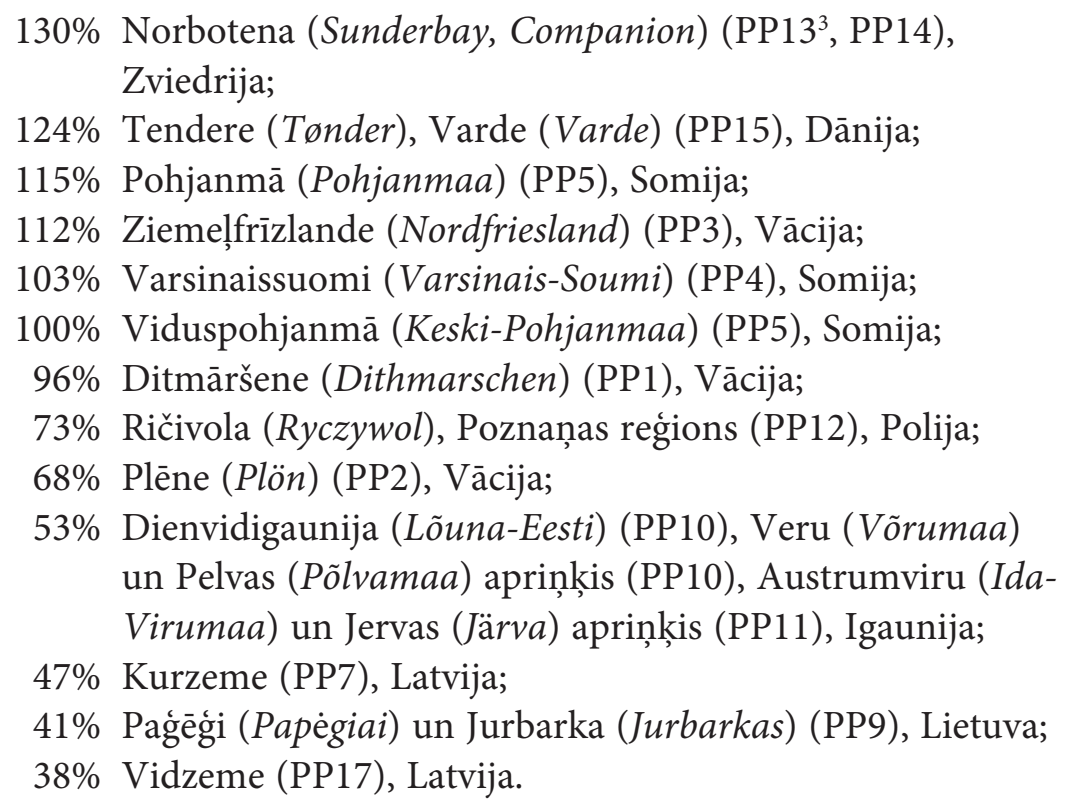

Lai arī kvantitatīvie sociālo parādību mērījumi ir aptuveni rādītāji, tomēr tie sniedz gana labu priekšstatu. Spēcināšanas vietās pirktspējas rādītāji rāda atškiriības. Tie uzskatāmi liecina par zināmu sociālo faktu - Skandināvijas valstu ekonomiskās un sociālās labklājības augsto līmeni, kas panākts vairāku faktoru ietekmē, ieskaitot arī labu valsts pārvaldību, valsts iekšpolitikas veidotājus un lēmumu pieñēmējus. Par Zviedriju ir piebilstams, ka šì valsts nav cietusi no Otrā pasaules kara postījumiem. Arī tāds subjektīvais rādītājs kā dažādu valstu iedzīvotāju laimes izjūta (pat ja to pārlieku nopietni neuztveram) Skandināvijas valstīs ir visaugstākais.

Šis un turpmākie šādi saīsinājumi nozīmē 'projekta partneris'. Pievienotais cipars ir partnera numurs SEMPRE projekta pieteikumā (A. S.). 
Vācija pēc sociālekonomiskiem rādītājiem pieder pie sociālās labklājỉbas valstu grupas, tomēr projektā izraudzìto vietu pirktspējas standarta rādītāji ir atšķirīgi. Tie uzrāda nevienlīdzību un neviendabību ne vien visā Vācijā, bet pat vienā federālā zemē - Šlēsvigā-Holšteinā. Ziemeḷfrīzlandes pirktspējas standarts ir augstāks par Eiropas Savienības vidējo rādītāju, turpretim Ditmāršenē tas ir nedaudz zemāks, bet Plēnē tas tuvojas Baltijas valstu rādītājiem, kas ir krietni zemāki par Eiropas Savienības vidējiem pirktspējas standarta rādītājiem. Baltijas valstu zemo pirktspējas rādìtāju cēloṇi ir meklējami to vēsturiskajā attīstībā - politisko režīmu pārmain̄ās, 90. gadu privatizācijā, kas tika īstenota pēc "laupītāju likumiem", lai pēc neatkarības atgūšanas 1991. gadā iegūtu ekonomisko kapitālu. Bezatbildīgā pārvaldība l̦āva visam notikt pašplūsmā, nerūpējoties par sabiedrības kopējo labumu un attīstību.

\subsection{SEMPRE projekta vietu apdzīvotības blīvuma rādītāju salīdzinājums}

Apdzīvotības blīvuma rādītājs ir mērījums, ar kuru tiek izteikts vidējais iedzīvotāju skaits uz vienu kvadrātkilometru.

Ja apdzīvotības blīvuma statistiskos datus par vidējo cilvēku skaitu uz vienu kvadrātkilometru izkārto dilstošā secībā, veidojas šāda iedzīvotāju skaita uz vienu kvadrātkilometru rādītāju rinda ${ }^{4}$ :

117,2 Ričivola, Poznaņas regions (PP12), Polija;

117,0 Plēne (PP2), Vācija;

92,9 Ditmāršene (PP1), Vācija;

81,6 Tendere, Varde (PP15), Dānija;

77,8 Ziemel̦frīzlande (PP3), Vācija;

44,3 Varsinaissuomi (PP4), Somija;

24,2 Paǵēgi un Jurbarka (PP9), Lietuva;

23,3 Pohjanmā (PP5), Somija;

20,7 Dienvidigaunija (PP10, PP11), Igaunija;

19,5 Kurzeme (PP7), Latvija;

4 Avots: Population Density, 2013. Available: http://ec.europa.eu/eurostat/web/ regions/data/database. 
13,7 Viduspohjanmā (PP5), Somija;

13,6 Vidzeme (PP17), Latvija;

2,6 Norbotena (Sunderbay, Companion) (PP13, PP14), Zviedrija.

Iedzīvotāju blīvums vienā kvadrātkilometrā uzrāda interesantu sakarību: tās vietas, kas ekonomiski labklājīgajās Skandināvijas valstīs (Somijā un Zviedrijā) ir iekḷautas SEMPRE projektā, atkarībā no to geogrāfiskā izvietojuma ziemel̦u-dienvidu virzienā uzrāda vidēji zemu apdzīvotības blivumu $(44,3)$, zemu apdzìvotības blīvumu, kas ir tuvs Baltijas valstu iedzìvotāju izkliedei $(13,7)$, un l̦oti zemu apdzīvotības blīvumu Norbotenas lēnē Zviedrijas ziemelıos $(2,6)$. Tur dzīvojošo skaits ir vidēji 2,6 cilvēki uz vienu kvadrātkilometru. Skaudrie klimatiskie apstākḷi Somijas un Zviedrijas ziemeḷu regionos ir tikpat nopietns retas apdzīvotības faktors kā skaudrie sociālekonomiskie dzīves apstākḷi, kas iekustinājuši iedzīvotāju plūsmas urbanizācijai un emigrācijai. Augstais bezdarba līmenis un sociālo pakalpojumu pieejamìbas samazināšanās laukos ir motivējusi darbspējīgā vecuma lauku iedzīvotājus gan pārcelties uz pilsētām, gan masveidā, pievienojoties pilsētniekiem, emigrēt no valsts. Šāda emigrācija bija vērojama pēc radikālām sociālekonomiskām pārmaiņām 90. gadu sākumā gan Baltijas valstīs, gan dažās citās valstīs, kas pāriet uz kapitālisma formāciju. Emigrācijas plūsmas paisuma viḷni veidojās, pakāpeniski ieviešot bezvīzu pārvietošanās režìmus ar daudzām valstīm, un 2004. gadā iestājās iedzìvotāju kustības brīvība visā Eiropas Savienības teritorijā, kad Eiropas Savienībā tika uzṇemtas Baltijas valstis.

\section{3. ledzīvotāju skaita pārmaiņu rādītāju salīdzinājums ${ }^{5}$ SEMPRE projekta vietās}

Iedzīvotāju skaita pārmaiṇu rādītāji sniedz informāciju par to, kā konkrētā vietā pieaug vai samazinās iedzīvotāju skaits un kā mainās iedzīvotāju vecumstruktūra, kā pieaug vai samazinās cilvēku skaits dažādās vecumgrupās.

Avots: Relative Population Change, 2011-2015. Available: http://ec.europa.eu/ eurostat/web/regions/data/database. 
Ja statistiskos datus par iedzīvotāju skaita pārmaiṇām Eurostat statistisko vienību ietvaros salīdzina pēc relatīviem rādītājiem, tos sakārtojot dilstošā secībā, iegūstam šādu rādītāju rindu:

$+1,80 \%$ Pohjanmā (PP5), Somija;

$+1,62 \%$ Varsinaissuomi (PP4), Somija;

$+0,75 \%$ Viduspohjanmā (PP5), Somija;

$+0,73 \%$ Ričivola, Poznaṇas reǵions (PP12), Polija;

$+0,55 \%$ Norbotena (Sunderbay, Companion) (PP13, PP14),

Zviedrija;

$+0,20 \%$ Tendere, Varde (PP15), Dānija;

$-1,57 \%$ Ditmāršene (PP1), Vācija;

$-1,98 \%$ Ziemeḷfrīzlande (PP3), Vācija;

$-3,16 \%$ Dienvidigaunija (PP10, PP11), Igaunija;

$-5,53 \%$ Plēne (PP2), Vācija;

$-6,06 \%$ Kurzeme (PP7), Latvija;

$-6,12 \%$ Vidzeme (PP17), Latvija;

$-6,72 \%$ Paǵẹgi un Jurbarka (PP9), Lietuva.

Iedzīvotāju skaita pārmaiṇu relatīvie rādītāji tiek sadalīti divās grupās - pieauguma un samazināšanās grupā. Pieaugumu uzrāda visu Skandināvijas valstu un Polijas SEMPRE projektā iekḷautās vietas. Iedzīvotāju skaita samazināšanās notiek visās Vācijas un Baltijas valstu SEMPRE projektā izraudzītās vietās. It kā paradoksāli šķiet rādītāji par iedzīvotāju skaita pieaugumu skaudrā klimata vietās Somijā un it îpaši Norbotenas lēnē Zviedrijas ziemeḷos. Būtisks faktors, kas nosaka šo tendenci, ir šo valstu imigrācijas politika. Ekonomiskās un sociālās labklājības magnētiskā pievilcība, kas SEMPRE projektā iekḷauto valstu vidū raksturīga Skandināvijas valstīm un Vācijai, motivē uz šejieni virzīties imigrācijas plūsmai no akūto un hronisko konfliktu valstīm, kas atrodas citos kontinentos, kā arī dažu valstu eiropiešiem. Tà kā imigrantus uzṇemošās labklājīgās Ziemel̦eiropas valstis pārvalda un kontrolē imigrantu izvietošanas procesu, pārdomāti izvietojot imigrantus un sadalot tos pa visas valsts teritoriju, tad daļa bēĝ̣u un imigrantu no siltajām dienvidu un dienvidaustrumu valstīm ir nonākuši Somijas un Zviedrijas teritorijās, kur raksturīgs ilgstošs aukstums un tumsa. 
Dabiskie iedzīvotāju skaita pārmaiṇu faktori, kas nosaka iedzīvotāju skaita samazināšanos Šlēsvigas-Holšteinas federālajā zemē Vācijā un Baltijas valstu SEMPRE projekta vietās, ir zemais dzimstības līmenis visās šajās valstīs un augstais mirstības līmenis Baltijas valstīs. Vispārēja urbanizācijas tendence, kas joprojām turpinās, ir cits faktors, kas ietekmē iedzìvotāju skaita samazināšanos lauku apdzìvotās vietās. Vienlaikus ar sen aizsākušos industrijas attīstību sākās arī urbanizācija, kas joprojām turpinās. Lauki zaudē kādu daļu no saviem jauniešiem un ekonomiski aktīvā vecuma iedzīvotājiem. Nepārtraukti notiek gados jauno un ekonomiski aktīvā vecuma iedzìvotāju iekšzemes kustība uz pilsētām, kur tiek turpināta izglìtība un ir vieglāk atrast un sasniegt darbavietu, kā arī tiek piedāvāti daudzveidīgi sociālie pakalpojumi un kultūras pasākumi.

Baltijas valstīs migrācijai uz pilsētām ir pievienojusies emigrācijas plūsma uz ārzemēm. Aizbraucēju skaits no Latvijas valsts ir dramatiski liels. Minētie faktori ir cēlonis tam, ka samazinās lauku iedzīvotāju skaits un šo iedzīvotāju vecumstruktūrā ir sākusi dominēt pirmspensijas vecumgrupa un vecuma pensijas saṇēmēju grupa.

\section{Aptaujas dati}

Partneru aptaujā par lokālās spēcināšanas tìkla vietu sociālekonomiskām īpatnībām, pakalpojumu galalietotāju dzīves apstākḷu novērtējumu un barjerām un šḳēešliem, kuri pastāv pakalpojumu sniedzēju darbavietās, ir saņemtas 14 anketas, kas aptver visas lokālo spēcināšanas tîklu vietas.

Aptaujas datu analīzes metodika ir tāda, ka iesākumā tiek uzskaitītas partneru sniegtās ziņas tādā secībā, kā tās nosaukuši partneri. Savukārt partneru secība veidota pēc to numerācijas projekta ieteikumā. Ja tā pati vai nedaudz citādi formulēta informācija par vienu un to pašu tematu atkārtojas, tā tiek pievienota, norādot partnera numuru un atrašanās vietu. Kad visa partneru sniegtā informācija par vienu jautājumu bloku ir sakārtota vienotā uzskaitījuma sarakstā, tā tiek apkopota un tiek izdarīti secinājumi. Raksta nobeigumā, kad ir apkopoti visi partneru sniegtie fakti, novērojumi vai novērtējumi, tiek doti daži ieteikumi. 


\subsection{Lokālo spēcināšanas tīklu vietu sociālekonomisko ipatnību raksturojums}

Vispirms partneriem īsās formalizētās aptaujas anketā bija lūgums raksturot sava spēcināšanas tīkla vietas sociālekonomiskās ipatnības.

Par projektā iekḷauto vietu īpatnībām partneru atbildīgās personas ir sniegušas daudzveidīgas ziņas. Pirmās tika raksturotas ziṇas par tautsaimniecību konkrētā vietā.

Tautsaimniecības ipatnības: izteikta lauku dzīves vide ar lauksaimnieciskās ražošanas dominēšanu un sezonālu nodarbinātību (Plēne/PP2, Ziemel̦frīzlande/PP3, Varsinaissuomi/PP4), kalnrūpniecības reğions (Norbotena/PP13, PP14). "Šis ir ekonomiski vislabvēlīgākais regions Somijā” (Varsinaissuomi/PP4).

Bezdarbs ir izplatìta un specifiska lauku apdzivoto vietu problēma. Izṇēmums ir Dānija, kur bezdarba līmenis ir zems. Par nodarbinātību un bezdarbu tiek liecināts daudz un dažādos formulējumos: "augsts bezdarba līmenis" (Ziemeḷfrīzlande/PP3, Viduspohjanmā un Pohjanmā/PP5, Kurzeme/PP7, Pageégi un Jurbarka/PP9, Dienvidigaunija, Veru un Pelvas apriņkiis/PP10, Austrumviru un Jervas apriņkisis/PP11), "nodarbinātības problēmas" (Dienvidigaunija/PP10, PP11), "pieaug bezdarbs migrantu vidū, ilgtermiņa bezdarbs" (Norbotena/PP13, PP14), "ierobežots vietējais nodarbinātỉbas sektors, mazas nodarbinātības iespējas laukos - alternatīvā lauksaimniecība, pārtikas ražošana, mežizstrāde, amatniecība" (Vidzeme, PP17). Vēl par bezdarbu teikts: "augsts bezdarba līmenis jauniešiem ar zemu izglìtības līmeni un zemu pašcieņu” (Norbotena, Sunderbay/PP13, Vidzeme/PP17).

Zems bezdarba un augsts nodarbinātības līmenis ir Tenderē un Vardē, Dānijā. Šìm vietām salīdzinājumā ar Dāniju kopumā ir raksturīgs augsts nodarbinātības lìmenis mazos uzṇēmumos (Tendere un Varde/PP15) un "mazs skaits nodarbināto ar augstāko izglìtību" (Varde/PP15).

Iedzīvotāju sastāva īpatnības ir nākamais iesūtīto ziṇu temats par vietas specifiku. Ziņas par iedzīvotāju vecumgrupu sastāva īpatnībām ir šādas: "liels to iedzīvotāju skaits, kas vecāki par 65 gadiem" (Plēne/PP2, Varsinaissuomi/PP4, Kurzeme/PP7, Dienvidigaunija/ PP10, PP11). Daži partneri to formulē tā: "vecumgrupa 50+" veido 54\% no iedzìvotājiem (Ziemeḷfrīzlande/PP3, Pag̣ēgèi un Jurbarka/PP9). 
Varsinaissuomi/PP4 partneri no Vāsas, kuriem sociāās spēcināšanas mērḳgrupa ir vecāka gadagājuma personas, ziņas par lielo vecāka gadagājuma cilvēku skaitu precizē ar informāciju, ka daudzi no viņiem dzīvo vieni, ir izolēti, mīt savās mājās neatkarīgi no citiem. "Urbanizācija nav apstājusies. Tas nozīmē, ka mūsu lauku apvidi zaudē jaunos darbspējīgos cilvēkus un te paliek vecāka gadagājuma cilvēki." (Norbotena/PP13, PP14)

Dāṇu informators šo procesu raksturo ar frāzi "novecojoši iedzīvotāji" (Tendere un Varde/PP15), informators no Latvijas: "Gados jauno emigrācijas sekas ir novecojusī sabiedrība.” (Vidzeme/PP17)

Cita vietu īpatnība saistîbā ar iedzīvotājiem ir iedzìvotāju skaita samazināšanās - "migrācija uz pilsētām un ārzemēm: gados jaunie pamet lauku dzīves vidi” (Kurzeme/PP7, Dienvidigaunija, Veru un Pelvas apriņkis/PP10, Austrumviru un Jervas apriņkis/PP11, Vidzeme/ PP17) vai "emigrācija” (Pagégéi un Jurbarka/PP9), vai "mazs iedzīvotāju skaits un zems iedzìvotāju blīvums" (Dienvidigaunija/PP10, PP11, Vidzeme/PP17).

Imigrācijas vilnis (Ziemeḷfrīzlande/PP3, Viduspohjanmā un Pohjanmā/PP5) ir cita nosauktā vietu sociālekonomiskā īpatnība.

Mobilitāte reǵionos ir aktuāls jautājums. Mobilitāte, lietojot sabiedrisko transportu, ir sarežgìta un apgrūtināta. Tas raksturots tā: "Sabiedriskā transporta problēmas lauku apdzīvotās vietās." (Plēne/ PP2, Kurzeme/PP7, Dienvidigaunija/PP10, PP11, Ričivola, Poznaņas reğions/PP12, Tendere/PP15, Vidzeme/PP17)

Daudzējādā ziṇā labklājīgās Dānijas īpatnība saistībā ar sabiedriskā transporta pieejamību tiek raksturota tā:

Zìmīgs Tenderes ekonomiskās un sociālās ainavas elements ir relatìvi rets vietējais sabiedriskais transports. Lai arī vietējais autocelı tùkls Tenderes iedzīvotājiem ḷauj pārvietoties pa visu reǵionu, vietējais sabiedriskais transports nepielauj šo fleksibilitāti. Tenderes iedzìvotāji, lai bùtu mobili, ir vislielākā mērā atkarīgi no personīgās automašinnas [..] (Tendere/PP15)

Mobilitātes ierobežojumus lauku dzīves vidē, ja ir nepieciešams lietot sabiedrisko transportu, informators no Plēnes ir iekḷāvis atbildē uz otro jautājumu par faktoriem, kas ietekmē pakalpojumu lietotāju dzīves apstākḷus: 
Galalietotāju grupa (ilgstoši bezdarbnieki - A. S.) bieži vien dzīvo mazos ciematos, kas atrodas tālu no lielākām pašvaldībām. Vini ir ierobežoti mobilitātē, ja viniem nav personīgās automašīnas, jo bieži tur nav iespējams nokḷut ar autobusu vai vilcienu.

Vēl ir nosauktas šādas vietu īpatnību pazīmes:

- augsta deviantās uzvedības koncentrācija (Pagégéi un Jurbarka/ PP9);

- augsts nabadzības kultūras demonstrācijas līmenis (Pageégi un Jurbarka/PP9, Dienvidigaunija/PP10, PP11);

- augsta atkarība no sociāliem pabalstiem (Pagégégi un Jurbarka/ PP9);

- depresīva teritorija, kas reiz bija smagās industrijas centrs Igaunijā, tajā ir izplatītas profesionālās slimības un ir liels skaits krieviski runājošu iedzīvotāju, kuriem nav Igaunijas pilsonības (Dienvidigaunija/PP10, PP11);

- augsti kvalificētu profesionāļu - ārstu, medmāsu, skolotāju, inženieru un menedžeru - trūkums Norbotenas lēnē Zviedrijā (Norbotena/PP13, PP14, Vidzeme/PP17);

- laukos ir augsts institucionalizācijas līmenis cilvēkiem ar garīgās attīstības traucējumiem (Vidzeme/PP17).

\section{Secinājumi par lokālo spēcināšanas tīklu vietu sociālekonomiskām īpatnībām}

Dati rāda, ka, salīdzinot ziņas par astoṇu Baltijas jūras reǵiona valstu SEMPRE projektā pārstāvēto vietu sociālekonomiskām īpatnībām, tajās ir vērojamas gan līdzības, gan atškikirības. Kopīgais ir piederība pie Eiropas Savienības - pie vienas un tās pašas politiski ekonomiskas savienības, kopīgs ir geogrāfiskais reǵions - atrašanās Baltijas jūras krastos, lai gan klimatiskos nosacỉjumus būtiski ietekmē geogrāfiskā atrašanās vieta. Vispārināti kopīgo un atšḳirīgo var grupēt vairākos tematiskos blokos.

\section{Vispārīgās attīstības īpatnības}

Vēsturiskie notikumi ir ietekmējuši valstu ekonomisko attīstîbu, ètiskos standartus un domāšanas veidu. Zviedrija ir vienīgā no Baltijas jūras reǵiona valstīm, kas nav pieredzējusi tiešu Otrā pasaules kara ietekmi, un tās attīstībā nav notikušas radikālas politiskās un 
ekonomiskās sistēmas pārmaiṇas. Visas pārējās Baltijas jūras reǵiona valstis ir postìtas Otrajā pasaules karā. Dānijai un Somijai ir līdzīga sociālekonomiskā attīstība, bet ir atšķirīga vēstures gaita, geogrāfiskais stāvoklis un klimats. Austrumvācijai un Polijai ir sociālistiskās orientācijas attīstības pieredze, bet tādas nav Šlēsvigas-Holšteinas federālajai zemei kā bijušās Rietumvācijas sastāvdaḷai.

Visām trim Baltijas valstīm ir līdzīga attīstìbas gaita 20. gadsimtā, un tās ir piedzīvojušas radikālas sociālekonomiskas pārmaiņas 90. gadu sākumā. Ekonomikas globalizācija ir pēdējā universālā tendence, kas ietekmē visas pasaules attīstību.

\section{Projektā ietverto vietu ekonomiskās īpatnības}

Partneri ir minējuši tādas ekonomiskās īpatnības kā sezonālā nodarbinātība, kas ir pašsaprotama lauksaimniecībā, mazo un vidējo uzņēmumu dominēšana, kalnrūpniecība kā nodarbinātības pamatjoma Zviedrijas ziemelıos. Nodarbinātības iespēju ierobežojumi ir visbiežāk minētā vietu ekonomiski problemātiskā ìpatnība. Augsts bezdarba lìmenis, vietu ekonomiskā depresija un cilvēku depresija ir izplatìta Baltijas jūras reǵiona valstīs. Augošs imigrantu bezdarba līmenis tiek norādīts Ziemel̦valstīs un Vācijā.

Salīdzinājumam - projekta vietās Dānijā ir l̦oti zems bezdarba līmenis un zems nodarbinātības līmenis privātajā sektorā.

\section{ledzīvotāju struktūras pārmaingas}

Iedzīvotāju struktūras pārmaiņas ir cits būtisks parādību kopums, kas informē par sociālo procesu tendencēm un apdzīvoto vietu īpatnībām.

Vispārinot projektā iesaistīto vietu īpatnības attiecībā uz to iedzīvotājiem, ir jāsecina, ka dominē divas tendences: iedzīvotāju novecošana un depopulācija jeb iedzīvotāju skaita samazināšanās reğionos. Izplatītākā kopīgā likumsakarība lauku dzìves vidē regionos ir iedzīvotāju novecošana. Tā ir uzrādīta septiṇās no astoņām Baltijas jūras reǵiona valstīm, Polija šai kontekstā ir vienīgais izṇēmums. Otra būtiskākā likumsakarība ir depopulācija jeb iedzīvotāju skaita samazināšanās. Iedzivotāju skaits laukos samazinās, jo turpinās urbanizācija, proti, liela dạ̧a jauniešu un darbspējīgā vecuma pieaugušo no visām lauku apdzīvotām vietām dodas uz lielākām pilsētām, lai turpinātu izglìtîbu 
vai meklētu darbu. Cits šo pašu motīvu vadīts migrācijas galamērḳis ir ārzemes, kā tas raksturīgi Baltijas valstīm un Polijai. Skandināvijas valstīs iedzīvotāju skaitu lauku dzīves vidē nedaudz palielina bēglu un imigrantu izmitināšana šajās vietās.

Migrācijas īpatnības projekta vietās ir pretēju virzienu migrācijas plūsmas. Migrācijas kontekstā esošās projektu vietas atspoguḷo šo valstu tipiskās iezīmes.

Sociālās un ekonomiskās labklājības valstis ir galamērḳis imigrācijas plūsmai no konfliktu un attīstības valstīm. Tādēl arī projekta partneriem no Dānijas, Somijas, Vācijas un Zviedrijas sociālās spēcināšanas izvēle ir tie profesionāl̦i, kas strādā ar bēgḷiem un imigrantiem, kā arī paši bēg̣̦i un imigranti. Kolēge no Dānijas šai sakarā zināja teikt, ka dāņu pārvaldības institūcijas ir smagi strādājušas, lai racionāli vadītu un ierobežotu imigrācijas procesu.

Postpadomju Baltijas valstîs pēc neatkarības atjaunošanas liela daļa iedzīvotāju atstāja savu valsti. Plašā izbraucēju plūsma veidojās galvenokārt sociālo un ekonomisko iemeslu dēl, tikai kāda neliela dą̣a izbrauca no valsts, lai iegūtu izglìtíbu un/vai meklētu dažādus piedzīvojumus.

\section{Infrastruktūras īpatnības}

Infrastruktūras stāvoklis un kvalitāte Baltijas jūras reg̣iona valstīs ir atšķirīgi. Piemēram, Latvijā lauku reǵionos daudzviet izzūd izglìīibas, veselības aprūpes, pasta, banku, veikalu pakalpojumu pieejamība. Cēloṇi tam ir racionālas un uz kopīgo sociālo labklājību orientētas pārvaldības trūkums, kas rezultējas finanšu nepietiekamībā sociāliem mērḳiem. Norbotenas lēnē Zviedrijā trūkst profesionāḷu medicīnas un sociālajā jomā.

Atsevišḳi izcel̦ams ir tāds infrastruktūras un sociālo pakalpojumu elements kā sabiedriskā transporta pakalpojumi un autocelı stāvoklis. Lauku dzīves vidē Latvijā mazinās sabiedriskā transporta pieejamība laukos un autocelı stāvoklis daudzviet ir slikts.

Projekta vietās Dānijā autoceḷu tìkls un kvalitāte tiek raksturota kā laba, bet sabiedriskā transporta pieejamība tur ir tik ierobežota, ka mobilitāte bez personiskās automašīnas ir l̦oti apgrūtināta, gandrīz vai neiespējama. Līdzīga situācija, kā liecina šo vietu pārstāvji, ir Plēnē un Ziemeḷfrīzlandē Vācijā. 


\subsection{Sociālo pakalpojumu galalietotāju dzīves apstākḷu raksturojums}

Lakoniskā formā sniegtā partneru informācija par faktoriem, kas ietekmē sociālo pakalpojumu galalietotāju dzīves apstākḷus, veido samērā garu sarakstu. Tiek pieminēti šādi faktori:

- pakalpojumi ir izkliedēti pa dažādiem birojiem, un ir dažādi pakalpojumu sniedzēji. To sasniegšanai nepieciešams laiks un naudas investīcijas cel̦a izdevumiem (Ditmāršene/PP1);

- netiek sniegta neatliekamā psihologiskā palīdzība Ditmāršenes pierobežas iedzīvotājiem (Ditmāršene/PP1);

- sabiedriskā transporta trūkums, mobilitātes apgrūtinājums (Plēne/PP2, Ziemel̦frīzlande/PP3, Kurzeme/PP7);

- bērnu aprūpes trūkums vecāku darba laikā vai arī augstas izmaksas par bērnu pieskatīšanu darbadienas laikā (Plēne/PP2);

- grūti dabūt darbu bezdarbniekiem, īpaši ilglaicīgiem bezdarbniekiem, regiionā dominējošos mazos un vidējos uzṇēmumos (Plēne/PP2);

- mazs subsidēto darbavietu skaits personām ar invaliditāti (Kurzeme/PP7);

- sociālā uzṇēmējdarbība ir nepietiekami attīstīta (Kurzeme/ PP7);

- pārāk ilgs ir bēgḷa statusa iegūšanas laiks (Ziemeḷfrīzlande/ PP3);

- mājokḷu trūkums (Ziemeḷfrīzlande/PP3);

- lieli pārvaramie attālumi laukos (Varsinaissuomi/PP4, Ričivola/PP12);

- demogrāfiskām pārmaiņām atbilstošu pakalpojumu trūkums, jo pakalpojumi tiek centralizēti un datorizēti un vecāka gadagājuma personām laukos nav piemēroti (Varsinaissuomi /PP4);

- skaudrs klimats ziemā (Varsinaissuomi/PP4);

- rasisms un stigmatizācija (Viduspohjanmā un Pohjanmā/PP5);

- nepietiekamas valodas prasmes kavē iegūt izglìīibu un ir šķērslis integrācijai sabiedrībā (Viduspohjanmā un Pohjanmā/PP5, Norbotena (Sunderbay)/PP13, Tendere, Varde/PP15);

- finansiāli ierobežojumi un finanšu pratības deficìts personām ar invaliditāti (Kurzeme/PP7);

- vientulības diskomforts personām ar invaliditāti un vecāka gadagājuma personām (Kurzeme/PP7, Varsinaissuomi/PP4); 
- nedraudzīga līdzcilvēku attieksme pret personām ar invaliditāti (Kurzeme/PP7);

- izglìtības deficīts, trūkst profesionālās un vidējās izglìtíbas atkarīgām personām un viena vecāka gimenes pieaugušai personai (Paǵégi un Jurbarka/PP9);

- sociālo prasmju deficīts (Pagégéi un Jurbarka/PP9);

- neprasme tikt galā ar dažādām dzives situācijām (Paǵégi un Jurbarka/PP9);

- stigmatizācija par novirzi no tradicionālās ǵimenes modeḷa (Pagégéi un Jurbarka/PP9);

- pēc rehabilitācijas vielatkarīgās personas ar grūtībām spēj atgriezties sabiedrībā (Paǵēǵi un Jurbarka/PP9);

- alkoholisms (Dienvidigaunija, Veru un Pelvas apriņkis/PP10, Austrumviru un Jervas apriņkis/PP11);

- ǵimenes ir atšķirtas, jo darbu atrast var vien kaut kur tālumā (Dienvidigaunija, Veru un Pelvas apriņ̧̧is/PP10, Austrumviru un Jervas apriņ̧is/PP11);

- dažās dzīvesvietās nav veikalu (Dienvidigaunija, Veru un Pelvas apriņķis/PP10, Austrumviru un Jervas apriņķis/ PP11);

- vidējie ienākumi Austrumigaunijā ir zemāki par valstī vidējiem ienākumiem (Dienvidigaunija, Veru un Pelvas apriņkis/ PP10, Austrumviru un Jervas apriņkis/PP11);

- bezcerība, apātija, motivācijas trūkums (Paǵēǵi un Jurbarka/ PP9, Dienvidigaunija, Veru un Pelvas apriņ̧is/PP10, Austrumviru un Jervas aprin,kis/PP11);

- HIV/AIDS izplatība (Austrumviru un Jervas apriņkis/PP11);

- sociālā dezintegrācija pēc etniskās piederības (Austrumviru un Jervas apriņkis/PP11);

- kopigu tikšanās un pulcēšanās vietu trūkums a) jauniešiem (Ričivola, Poznaņas reğions/PP12), b) pamatiedzīvotājiem ar imigrantiem (Norbotena, Sunderbay/PP13);

- jaunatnes domas un viedokḷi netiek ņemti vērā, tos neuzskata par nopietniem (Ričivola, Poznaņas reǵions/PP12);

- imigrantu segregācija un diskriminācija (Norbotena, Sunderbay/PP13, Tendere, Varde/PP15);

- slikti dzīves apstākḷi - trūcīgi mājokḷi, kuros trūkst pamatērtības - tekošs ūdens, sanitārais mezgls (Vidzeme/PP17). 
Secinājumi par sociālo pakalpojumu lietotāju dzīves apstākḷiem

Fakts, ka pakalpojumu lietotāju kategorijas ir daudzveidīgas un ka dažkārt viena kategorija, piemēram, bezdarbnieki, tiek sazarota pēc kādas precizējošas pazimes, ir iemesls tam, ka dzīves apstākḷus raksturojošo pazīmju skaits ir liels. To ir ap 30.

Sociālo pakalpojumu sniedzēju nosauktos faktorus, kas ietekmē pakalpojumu lietotāju dzīves apstākḷus, var apvienot vairākās nozīmīgās grupās. Ir konstatējama tieša sakarība starp iepriekš uzrādītām vietu īpatnībām un sociālo pakalpojumu lietotāju dzives apstākḷus raksturojošām īpašībām. Tiek norādīti šādi faktori, kas ietekmē sociālo pakalpojumu lietotāju dzīves apstākḷus: ekonomiskie faktori, mobilitātes ierobežojumi, migrācija, iedzīvotāju novecošana, sabiedrības dezintegrācija, negativa sabiedrības attieksme, psihologiskas problēmas un pakalpojumu sniedzēju darba organizatoriskās nepilnības. Ieskatam apkopota informācija par šiem faktoriem.

Ekonomiskie faktori. Bezdarbs bieži tiek minēts kā faktors, kas dzīvi sarežg̀ì visiem, kurus tas skāris, vai tie būtu dažādu vecumgrupu vietējie iedzīvotāji, bēg̣̣i un imigranti vai personas ar invaliditāti.

Personām ar invaliditāti Latvijā dzives apstākḷus apgrūtina zemās invaliditātes pensijas.

Telpiski ierobežojumi ir ekonomisko faktoru apakšgrupa. Telpu trūkums tikšanās pasākumiem, ko piemin poḷu un Ziemel̦zviedrijas partneri, varētu būt daḷēji ekonomiski, daḷēji organizatoriski determinēts. Mājokḷu trūkums imigrantu izmitināšanai Ziemeḷfrīzlandē ir cits šai vietai raksturīgs ekonomiskā faktora paveids.

Mobilitātes ierobežojumi laukos ir sāpīga aktualitāte, jo sabiedriskais transports ir pieejams reti vai tikpat kā nepieejams. Dažās apdzīvotās vietās tas ir pārstājis kursēt vispār, jo pārvadātājiem peḷnas vietā ir zaudējumi. Dānijā un Vācijā, kur autocelı tìkls un kvalitāte ir nevainojami, sabiedriskais transports nekursē vai kursē tā, ka sociālie pakalpojumi un darbavieta ir nepieejami, ja nav savas automašīnas. Latvijā ir ne vien sabiedriskā transporta aizvien ierobežotāka pieejamība reǵionos, bet arī kritisks autocel̦u un zemes ceḷu stāvoklis daudzās vietās reǵionos.

Tālās distances regionos ir cits faktors, kas apgrūtina mobilitāti un ietekmē sabiedriskā transporta pakalpojumu pieejamību. To piemin somu un poḷu partneri. 
Migrācija uz pilsētām un ārzemēm, kas ir izplatīta jauniešu vecumā un ekonomiski aktīvu cilvēku vidū, maina iedzīvotāju vecumstruktūru, pasliktina vietu ekonomisko stāvokli, samazina sociālo pakalpojumu piedāvājumu lauku apdzīvotās vietās. Urbanizācijas tendence ietekmē iedzīvotāju vecuma sastāvu visās Baltijas jūras regiona valstīs, to papildus iespaido jauniešu un ekonomiski aktīvo iedzivotāju emigrācija uz ārzemēm, kas ir izplatīta parādība Igaunijā, Latvijā un Lietuvā.

Iedzivotāju novecošana lauku dzīves vidē, kas izpaužas kā vecāka gadagājuma iedzīvotāju īpatsvara palielināšanās, ir sekas iepriekš minētai gados jauno cilvēku migrācijai no laukiem uz pilsētām un/vai ārzemēm.

Sabiedrības dezintegrācija pèc piederības pie citas rases un etnosa, proti, pie visāda veida imigrantiem, tiek dokumentēta bieži. Igaunijā tā izpaužas attieksmē pret "krievu valodas nesējiem", Dānijā, Somijā, Vācijā un Zviedrijā - pret imigrantiem no akūtu (Sīrija) un hronisku vardarbīgu konfliktu valstīm (Afganistāna, Irāka), kur ekonomika ir sagrauta un normāli dzìves apstākḷi ir iznīcināti.

Negatìvā sabiedrības attieksme pret citādību savā ciltī un ienācējiem no ārienes ir biolog̣iski un tradīciju determinēta parādība. Igaunijā, Dānijā, Somijā, Vācijā un Zviedrijā tiek norādīts uz negatīvu attieksmi pret jauniem un seniem imigrantiem vietējās valodas nezināšanas un kulturālo atšksirību dẹḷ.

Negatīvā sabiedrības attieksme pret svešiniekiem ir sensena biologiski, psiholog̣iski un tradīcijās nostiprinātu uzvedības ieradumu determinēta reakcija. Tā ir saistīta ar drošību, ar izvairīšanos no riska tikt apdraudētam. Tāda attieksme ir pašsaglabāšanās instinkta izpausme. Šì negatīvā attieksme pret citādo un nepazīstamo ir viens no sabiedrības dezintegrācijas vektoriem (Simmel, 1992).

Cits sabiedrības dezintegrācijas vektors ir ètiski attaisnojamā negatīvā attieksme pret devianto uzvedību - kaitīgām atkarībām, vardarbību, noziedzību. Partneru biežāk minētais deviantās uzvedības paveids, kas raksturo un ietekmē dzìves apstākḷus, ir vielatkarības. Alkoholisms un narkomānija ir igauņu, latviešu un lietuviešu partneru nosauktais faktors, kas negatīvi ietekmē sociālo pakalpojumu lietotāju dzìvi. Negatīva sabiedrības attieksme pret personām ar destruktīvu un deviantu uzvedību ir pozitīvi vērtējama kā garīgi un morāli veselīgas sabiedrības daļas slavējama reakcija.

Psihologiskas problēmas var nopietni ietekmēt cilvēku iekšèjo komfortu un dzìves izjūtu. Sociālo pakalpojumu lietotājiem 
psihologiskas problēmas ir dziḷas un plaši izplatītas. Igauņu, latviešu un lietuviešu partneri min tādus psihologiskus stāvokḷus kā bezcerība, apātija, motivācijas trūkums, sociālo prasmju deficìts, neprasme tikt galā ar dažādām dzìves situācijām. Vientulība kā diskomforta izjūta tiek pieminēta saistībā ar vecāka gadagājuma personām Somijā un personām ar invaliditāti Latvijā.

Aptaujā vācu partneri norāda uz pakalpojumu sniedzēju darba organizatoriskām nepilnībām Ditmāršenē. Tās kā nopietnu šḳērsli uzrāda arī Latvijas, Somijas un Vācijas sociālās labklājības eksperti padzilinātā aptaujā par barjerām un škēeššliem sociālo pakalpojumu sniegšanā.

\subsection{Barjeras un šķēršşli sociālo pakalpojumu sniedzēju darbā}

Par barjerām un šḳēršlıiem, ar ko nākas sastapties, sniedzot sociālos pakalpojumus, tika jautāts sociālo pakalpojumu organizāciju profesionāliem formalizētajā aptaujā. Atbildes uz jautājumiem par barjerām un šḳēršliem formāli netika ierobežotas. Tika piel̦autas visu veidu barjeras un šķērṣ̌li, kurus profesionāļi varēja darìt zināmus, izvērtējot savu reālo darbu, pārdomājot, kas vinu darbā neapmierina un būtu maināms. Par barjerām un šḳēršliem tika nosaukti ekonomiski, juridiski, organizatoriski, sociāli un kulturāli apstākḷi.

Nosaukto barjeru un šķēršlı uzskaitījums ir garš. Lai daudzveidīgā partneru sniegtā informācija saglabātu satura bagātîbu un izteiksmes stilu, tā tiek sniegta maksimāli pietuvināti partneru formulējumiem. Izteikumu secíba veidota, ievērojot partneru kārtas numuru. Tad, kad cits partneris izsakās par to pašu, kas ticis pieminēts iepriekš, partnera vieta un norāde uz kārtas numuru tiek pievienota tam apstāklim, kas atkārtojas. Barjeru un šķēršşu uzskaitijiuma analīzes rezultāts to tipologijas formā tiek sniegts šīs teksta sadal̦as nobeigumā.

Partneru formulējumos barjeras un šḳēršli veido turpmāk piedāvāto sarakstu.

Fokusēšanās uz esošiem pakalpojumiem un nevēlēšanās domāt par pārmaiņām (Ditmāršene/PP1).

Publisko finanšu samazināšanas izraisīts spiediens uz pakalpojumu sniegšanu (Ditmāršene/PP1).

Tradicionāls lomu modelis (Plēne/PP2). 
Motivācijas trūkums pakalpojumu saṇēmēju vidū (Plēne/PP2, Kurzeme/PP7, Paǵēǵi un Jurbarka/PP9).

Nevēlēšanās doties uz citām vietām darba meklējumos, jo darbojas ieraduma spēks un bailes atstāt ierasto lauku vidi (Plēne/PP2).

Bēgḷu un imigrantu izvairīgās atbildes par vēlamo dzīvesvietu ir šḳērslis viņu ātrākai integrācijai (Ziemel̦frīzlande/PP3).

Pakalpojumu sniedzēju lietotāju valodas nezināšana (Ziemel̦frīzlande/ PP3). Imigrantu nepietiekamas vietējās valodas zināšanas (Tendere, Varde/PP15).

Kulturālas atškịīibas ir nesaprašanās cēlonis par religiskām un dzimumu lomām (Ziemeḷfrīzlande/PP3).

Bēgḷiem ir kara izraisìtās psihologiskās traumas (Ziemeḷfrīzlande/PP3). Grūtības sameklēt un sasniegt reālos vai potenciālos visievainojamākos pakalpojumu sañēmējus (Varsinaissuomi/PP4, Kurzeme/PP7). Pāreja no speciāliem bēĝ̣u integrācijas pakalpojumiem uz pakalpojumu sniegšanu bēgliem pēc vispārējiem noteikumiem ir kritiska bēg̣̣u spēcināšanai (Viduspohjanmā/PP5).

Zems pakalpojumu lietotāju izglìtības līmenis (Pageẹgi un Jurbarka/ PP9).

Sociālo prasmju un situāciju risināšanas prasmju trūkums pakalpojumu saņēmējiem (Pageẹgi un Jurbarka/PP9).

Speciālo darba prasmju iztrūkums sociālo pakalpojumu sniedzējiem, nepietiekama specializācija personālam sociālo pakalpojumu organizācijās (Pagégéi un Jurbarka/PP9, Dienvidigaunija, Austrumviru un Jervas aprinkis/PP11).

Nepietiekama komunikācija starp dažādu municipalitāšu sociālo pakalpojumu sniedzējiem (Dienvidigaunija, Veru un Pelvas apriņķis/PP10, Austrumviru un Jervas apriņkis/PP11).

Sociālo pakalpojumu sniedzēju un san̦ēmēju atškirīigie uzskati par vajadzībām un palīdzības formām (Dienvidigaunija, Veru un Pelvas apriņkis/PP10, Austrumviru un Jervas apriņ̧⿻is/PP11).

Būtu vajadzīga "daudzfunkcionāla" pakalpojumu sniedzēju komanda, kurā strādātu psihologs, finanšu speciālists un pastorāls padomdevējs (Dienvidigaunija, Austrumviru un Jervas aprin,ķis/PP11). Vecāka gadagājuma personām ir nepieciešami datorpratîbas apmācību pakalpojumi, jo daudzi pakalpojumi pieejami tikai ar interneta starpniecību (Dienvidigaunija, Austrumviru un Jervas apriņkis/ PP11). 
Draudzīgas sadzivošanas tradīciju trūkums. Seniori ir vientuli, vienlaikus gimenēm ar bērniem ir vajadzīga vecvecāku palīdzība (Dienvidigaunija, Austrumviru un Jervas apriņkis/PP11).

Informācijas deficīts (Dienvidigaunija, Austrumviru un Jervas apriṇkis/PP11).

Cilvēkiem bez pilsonības ir nepieciešamas konsultācijas, jo viṇi nav integrēti, ir neinformēti par darba tirgu, par sociāliem pabalstiem, nacionālās valodas mācǐšanās iespējām un pilsoniskās sabiedrības mehānismiem (Dienvidigaunija, Austrumviru un Jervas apriṇkis/ PP11).

Telpu trūkums, kur pulcēties jauniešiem vai kur pulcēties iezemiešiem ar imigrantiem (Ričivola, Poznaņas regiions/PP12, Norbotena, Sunderbay/PP13).

Starppaaudžu konflikts un nesaprašanās, attieksme "mēs darām jums" tā vietā, lai teiktu "mēs darām kopā ar jums" neveicina jauniešu līdzdalibu (Ričivola, Poznaṇas reğions/PP12).

Pēc kursu "Zviedru valoda imigrantiem" pabeigšanas un 24 mēnešu individuālās integrācijas plāna daudzi imigranti paliek par bezdarbniekiem. Sabiedrība vinus maz atbalsta (Norbotena, Sunderbay/PP13).

Segregācijas problēmas starp iedzimtajiem un imigrantiem (Norbotena, Sunderbay/PP13).

Grūti atrast tos jauniešus, kuriem ir zems izglìtïbas lïmenis un nav darba un kuri riskē kḷūt par ilgtermiņa bezdarbniekiem. Ir nepieciešami jauni instrumenti, kā viniiem palīdzēt atrast personiskus mērķus un sniegt atbilstošu izglitību (Norbotena, Companion/PP14). Vidzemes partneris nosauc garu barjeru un šḳēršlı uzskaitījumu, kas nodēvēts par ierobežojumu kompleksu darbā ar jauniešiem, kam nav izglitīibas, prasmju un darba. Ja garo uzskatījumu reducē uz būtiskāko, tad būtiskākais ir ierobežota sociālo pakalpojumu un sabiedriskā transporta pieejamíba regionos, ierobežotas finanses, nepietiekama komunikācija un nepietiekama darbu koordinācija starp dažādām institūcijām. Sociālo pakalpojumu sniedzējiem trūkst pieredzes darbā ar šādas kategorijas jauniešiem, lokālās jauniešu organizācijas strādā vienīgi ar līderiem, vecāku iesaistī̌sanos kavē laika un finanšu trūkums (Vidzeme/PP17).

Sarežğìta juridiskā infrastruktūra, kā koordinēt dažādu pakalpojumu veidus (Tendere, Varde/PP15). 
Apjomīga dokumentācija, "papīra darbu" daudzums, ko liek darìt sarežg̀itā juridiskā infrastruktūra, ir tik liels, ka bēglu vidū izraisa sajūtu, ka tiek ierobežota vinu iesaistīšanās sabiedrībā. Tas ietekmē viṇu spēcināšanu tādējādi, ka tā pārvēršas par savu pretstatu - viṇu vājināšanu (Tendere, Varde/PP15).

Tāds ir barjeru un šķērš̌lu apkopots uzskaitījums pēc partneru sniegtajiem datiem.

Pirms tipologiizēt barjeras un šķērš̌lus un izdarìt secinājumus par barjerām un šḳēršliem sociālo pakalpojumu sniegšanā, te apkopotiem visu partneru datiem ir pievienojama padziḷināta informācija par barjerām un šķēršsliem sociālo pakalpojumu organizāciju darbā. Papildinformāciju ir snieguši Latvijas, Somijas un Vācijas eksperti sociālo pakalpojumu sfērā.

\section{Padziļināta Latvijas, Somijas un Vācijas ekspertu informācija par barjerām un škēršliem sociālo pakalpojumu organizāciju darbā}

Barjeru un šḳēššlu padziḷinātai apzināšanai tika izvirzìts moto: apzināt savas vājās puses ir ceḷšs, kā tās pārvarēt un kḷūt stiprākiem.

Metodologija. Lai iegūtu padziḷinātu informāciju par barjerām un šḳēeš̌liem sociālo pakalpojumu organizāciju darbā, 2017. gada jūnijā un jūlijā tika veikta lokālo spēcināšanas tīklu ekspertu aptauja Latvijā, Somijā un Vācijā. Aptaujas instruments ir dal̦ēji strukturēta anketa. Aptaujas mērḳis - iegūt padziḷinātu informāciju par barjerām un šķēršlliem sociālo pakalpojumu organizāciju darbā, kā arī verificēt 2016. gada pirmajā pusē partneru sniegto informāciju par barjerām un šḳēršlliem organizāciju darbā un uzzināt par pārmaiṇām organizāciju darbā šai laikposmā. Latvija, Somija un Vācija tika izvēlētas, kombinējot racionālu izvēli un nejaušības principu. Racionalitāte tika likta lietā, sadalot visas astoņas ES Baltijas jūras regiona valstis trīs atškirīgās valstu grupās - Baltijas valstis, Skandināvijas valstis un Centrāleiropas valstis. Pēc tam tika izlozēta viena valsts no katras grupas. Kopumā tika veiktas 16 ekspertu aptaujas, piecas - Latvijā, četras - Somijā, septiṇas - Vācijā.

Šoreiz daḷēji strukturētās anketas plāns ir izvērstāks un tajā tiek piedāvāts faktoru kopums, kas ietekmē būtiskāko sociālo pakalpojumu organizāciju darbu un kas ir gan noskaidrojies iepriekšejā aptaujā, gan ticis fiksēts citos avotos praksē un teorijā. Respondentiem ir dota iespēja brīvi papildināt savas atbildes. 
Informācijas analīzē barjeras un šķērš̌li tiek sadalīti divās lielās grupās. Tās ir klasificētas kā materiālās un nemateriālās barjeras un šķēršși. Katrai grupai ir pakārtotas vairākas apakšgrupas. Tiek definēta barjeru un šķērṣ̌ı specifika, nosakot, ka barjeras ir ar cilvēku saistīti subjektīvi iekšējie faktori, turpretim šḳērṣ̌̆i ir lielā mērā objektīvi ārējie faktori. Ir izveidots šāds darbu ietekmējošo faktoru sadalījums:

1. Materiālie šķēešs̆li.

1.1. Finansējums sociālo pakalpojumu sniegšanai.

1.2. Sociālo pakalpojumu sniedzēju zemais atalgojums.

1.3. Darba telpu stāvoklis.

1.4. Sabiedriskā transporta pieejamība.

2. Nemateriālās barjeras un šḳ̂ēršli.

2.1. Darbības juridiskā regulācija.

2.2. Barjeras un šḳērṣ̌i, kas saistìti ar personālu un tā darba apstākḷiem.

2.2.1. Profesionāla personāla pieejamība.

2.2.2. Personāla specializācija.

2.2.3. Birokrātiski šḳēršli (pārmērīgs dokumentācijas producēšanas daudzums).

2.2.4. Psihologiskas barjeras.

2.2.5. Societālas barjeras.

2.2.6. Horizontālās un vertikālās komunikācijas kvalitāte un darbu koordinācijas kvalitāte.

2.2.7. Svešvalodu zināšanu deficīts.

2.2.8. Cilvēciskais faktors un tā kvalitāte varas/pārvaldības struktūrās.

2.2.9. Citas barjeras un šķēršli.i.

\section{Empīriskās informācijas analīzes rezultāti}

2016. un 2017. gadā veiktajās aptaujās pārmaiņas barjeru un šḳēršlı apzināšanā nav konstatētas.

No jauna iegūtā informācija pārsvarā ir saistīta ar personālu un nemateriāliem faktoriem - psihologiskām barjerām, komunikāciju, darba koordināciju, sabiedrības attieksmi pret sociālo pakalpojumu lietotājiem. Taču tiek norādīts arī uz finansējuma nepietiekamību. 


\section{Finansējuma nepietiekamība pakalpojumu sniegšanai un personāla atalgošanai}

Par materiāliem šķērš̌liem sociālo pakalpojumu sniedzēju darbā tiek liecināts galvenokārt divos aspektos. Viens no tiem ir vajadzība palielināt finansējumu vietējās valodas mācībām bēgliem un imigrantiem, lai viņi varētu sekmīgāk integrēties iecel̦ošanas zemes sabiedrībā. Otrs ir personāla zemais atalgojuma līmenis sociālo pakalpojumu un sociālās aprūpes iestādēs. Fiziski un psihologiski smagā darba prestižu stipri pazemina zemais atalgojums. Tādēḷ ir personāla deficìts. Būtisks personāla deficita iemesls ir zemais atalgojums par šo psihologiski saspringto darbu, kas personāla deficīta un/vai darba organizācijas dēl reizēm veicams pārslodzes režīmā. Mana pieredze mācību darbā ar sociālā darba studentiem liecina, ka dal̦a jauniešu, kas apguvuši šo specialitāti, nevēlas strādāt šajā, vinuuprāt, nepievilcīgajā jomā. Par nepievilcīgu tiek uzskatīts atalgojuma līmenis, darba apstākḷi un bieži sastopamās psiholoǵiski un sociāli smagās situācijas, kurās atrodas pakalpojumu lietotāji. Personālam tas izraisa distresu un hiperstresu.

Pakalpojumu sniedzēju darba nozīmes nenovērtēšana, kas izpaužas zemajā atalgojumā, izraisa viņos netaisnības izjūtu un pazemojuma jūtas. To, ka pacietības mērs ir pilns un klusēšana ir jāpārtrauc, liecināja Latvijas sociālās aprūpes centru darbinieku arodbiedrības paziṇojums, ka, protestējot pret zemo atalgojumu, kas sociāliem aprūpētājiem Latvijā ir valstī noteiktās minimālās algas apjomā (2018. gadā tās bruto apjoms ir 430,00 eiro mēnesī), vini 2018. gada 28. septembrī rìko astoṇu stundu bada streiku. Bada streiks ir noticis, un tika sāktas sarunas ar Labklājỉbas ministriju par algu palielināšanu. Ir neapšaubāma netaisnība par šo fiziski, psiholog̣iski un morāli smago darbu saṇemt atalgojumu, par kuru izdzìvot nav iespējams.

Tiesību normatīvā regulācija var būt un ir šķērslis sociālo pakalpojumu sniegšanā tajos gadỉjumos, kad likumu normas ir pretrunīgas, nav harmonizēti dažādu līmeṇu dokumenti, kā arī tad, kad notiek likumu reformēšana, tiek veikti grozijumi likumos vai stājas spēkā jauna likumdošana. Somijā likumdošanas reforma sociālajā jomā ir aktualitāte 2017. gada aptaujas laikā. Ja maina likumdošanu, kas saistīta ar sociālo palīdzību, tas vismaz uz laiku apgrūtina sociālo pakalpojumu sniedzēju darbu. 


\section{Profesionāla personāla deficīts sociālo pakalpojumu organizācijās}

Par profesionāla personāla nepietiekamo skaitu, tā atrašanas un piesaistī̌sanas grūtībām lauku vidē reǵionos informē Latvijas un Vācijas partneri. Abās valstīs reǵionos ir grūti piesaistìt jaunos speciālistus. Pašreizējais personāls tuvojas pensionēšanās vecumam, darbinieku skaits sociālo pakalpojumu jomā sarūk. "Mums jāpadara sociālais darbs atraktīvāks jauniem cilvēkiem," - atzīst sociālo pakalpojumu sniedzēji no Vācijas.

Viens no personāla deficīta iemesliem ir zemais atalgojums par šo psihologiski saspringto darbu, kas personāla deficìta un/vai darba organizācijas dēl reizēm veicams pārslodzes režìmā.

Psihologiskās spēcināšanas vajadzība tiek apliecināta kā nepieciešamība gan personālam, gan pakalpojumu lietotājiem. To uzsver Latvijas un Vācijas partneri. Latvijas pārstāvji vairākkārt apliecina psihologa kā patstāvīga organizācijas darbinieka vajadzību. Vācijas eksperti izsaka vēlmi savās problēmsituācijās saṇemt palīdzību no organizācijas vadības, savukārt ilgstošiem bezdarbniekiem ir akūti nepieciešams "stiprināt pamatemocijas un pašcieņu".

Personāla specializācija darbam ar noteiktu sociālo pakalpojumu lietotāju kategorijām ir apzināta nepieciešamība Latvijā un Vācijā, kur ir konstatēts, ka personālam trūkst zināšanu gan par mūsdienu idejām un teorijām, kas saistītas ar noteiktas kategorijas pakalpojumu lietotājiem, gan par praktisku rīcību, kontaktējoties ar noteiktas kategorijas pakalpojumu lietotājiem, piemēram, ar personām, kurām ir garīgās attīstības traucējumi un psihiski traucējumi. Personāla specializācija ir nepieciešama arī darbā ar tiem jauniešiem, kuriem ir zems izglìtỉbas lìmenis, nav prasmju un nav darba.

Birokrātiskie šḳēeršlıi, kas saistīti ar izvērstas dokumentācijas gatavošanu, pasliktina darbu un sociālo pakalpojumu lietotāju stāvokli, jo kontaktēšanās laiks, kas atvēlēts pakalpojumu lietotājiem, samazinās. "Mēs permanenti esam pārslogoti ar sociālo pabalstu maksājumiem un papīru kalniem," - liecina sociālo pakalpojumu sniedzēji no Latvijas. Taču tādas pašas sūdzības izskanējušas arī Dānijā.

Societālas barjeras. Par societālām barjerām tiek definētas tās barjeras, kas attiecas uz sabiedrību kopumā vai šajā gadījumā uz lielu sabiedrības daḷu. Te iztirzātā temata kontekstā tā tiek apzīmēta negatīva attieksme pret dažāda veida atšķirībām un novirzēm no sabiedrībā pieṇemtām uzvedības normām. Negatīva attieksme pret atšķirīibām un 
novirzēm izpaužas kā stigmatizācija, marginalizācija, diskriminācija, neiecietība, izslēgšana jeb atstumšana, kas var būt vērsta gan pret savas zemes citādajiem, gan pret svešzemniekiem: "Societāla atmosfēra pret migrantiem ir skaudra, un cilvēkiem (pat pakalpojumu sniedzējiem) ir sava pārliecība, kas nesaskan ar cilvēktiesībām” (Somija); “[..] naidīgums pret ārzemniekiem” (Vācija); “[..] stigmatizācija ir liela sabiedrības problēma (piemēram, viena vecāka gimenes tiek diskriminētas pat vietējo politiķu publiskās runās” (Vācija); “[..] sabiedrībā ir plaši izplatìta neiecietỉba un negatīva attieksme pret disfunkcionālām gimenēm un vinuu bērniem, [..] nabadzīgo ğimeņu materiāla atbalstī̌šna izraisa skaudību citos kopienas pārstāvjos, [..] cilvēki ir pret izmaksām un izdevumiem citu labā, vai tie būtu cilvēki ar invaliditāti, nabadzīgie, trūcīgie vai vielatkarīgie" (Latvija).

\section{Barjeras un šḳēršlı komunikācijā}

Daudzās atbildēs plaši izvērstais temats saistīts ar komunikāciju. Komunikācija cieši saslēdzas ar jau minēto psihologisko problemātiku, un abas rada daudz sarežǵijumu ikdienā un darbā. Tā kā komunikācijai ir divas asis - horizontālā un vertikālā, tad tās izraisìto iespējamo un reālo sarežğỉjumu lauks ir plašs. Horizontāli tā noris ar tā paša līmeņa kontaktpersonām. Vertikāli komunikācija noris padotībaspakḷautības skalā. Vertikāli komunikācija noris vienā organizācijā ar vadošo personālu, tāda tā var būt starp dažāda līmeṇa organizācijām. Un šì asimetriskā varas pozīcija gribot negribot izpaužas komunikācijā ar sociālo pakalpojumu lietotāiiem.

Par komunikāciju ar sociālo pakalpojumu lietotājiem tiek pausts, ka vecāka gadagājuma personas un ilgtermiņa bezdarbniekus ir grūti sasniegt un grūti sākt komunicēt ar viņiem. Ilgtermiņa bezdarbnieku dzīve nabadzībā un sociālā izolācijā rada kauna jūtas, un vinịi izvairās no komunikācijas ar citiem.

Ar bēg̣̣iem un imigrantiem komunikācija ir apgrūtināta valodas barjeras dēlı.

Komunikāciju var apgrūtināt nepietiekams personāla skaits, specializēta personāla aiziešana no darba, laika ierobežojumi, kādi ārēji šķēeššli un arī gan personāla, gan pakalpojumu lietotāju iekšêjās barjeras.

Savu ìpatnību komunikācijā var radìt sociālo pakalpojumu saṇēmēju emocionālie stāvokḷi un ieradumi. Latvijas sociālo pakalpojumu sniedzēji informē, ka dažkārt pakalpojumu lietotāji mēdz izgāzt savas 
dusmas uz sociālo dienestu personālu, mēdz būt neiecietīgi vai arī šantažè sociālo pakalpojumu sniedzējus.

\section{Komunikācija starp institūcijām un darba aktivitāšu koordinācija}

Komunikācija un rīcības koordinācija ir plašs nepieciešamo uzlabojumu un iespēju lauks. Tas ir jo cieši saistīts ar komunikācijas un informācijas aprites pilnveidošanu. Par nepilnībām komunikācijas plūsmās un darbību koordinācijā žēlojas Latvijas, Somijas un Vācijas pārstāvji. Somu partneri norāda uz "spēcīgu koordinācijas trūkumu starp vienas nozares aktoriem”, ko profesionāḷi mēgina pārvarēt, veidojot tìklošanos. "Trūkst darba koordinācijas starp sociāliem dienestiem un pakalpojumu sniedzējiem pieaugušo izglìtības un nodarbinātības jomā," liecina cits somu partneris. "Aktivitāšu koordinācijas deficītu” atzīst vēl trešais somu pārstāvis, piebilstot, ka tiek smagi strādāts, lai to pārvarētu. "Aktivitāšu koordinācijas deficītu" un vēlmi, lai būtu "labāka komunikācija starp atbildīgiem dienestiem, sabiedrības pārvaldības institūcijām un pakalpojumu sniedzējiem" vācu partneri piemin saistībā ar problēmu risināšanu darbā ar bēgliem. Nodarbinātības centriem trūkstot oficiālas informācijas par bēglu nodarbināšanas iespējām, integrēšanas kursiem, to uzdevumiem un mērķiem.

Informācijas un koordinācijas trūkumu darbā ar problemātiskajiem jauniešiem, kuriem nav izglítības, darba un prasmju, uzsver Latvijas partneri no Vidzemes: "[..] informācijas un aktivitāšu koordinācijas trūkums starp skolām, dažādām organizācijām un/vai departamentiem: šiem jauniešiem ir arī uzvedības problēmas skolā, viṇiem ir nosliece būt negatīviem un agresīviem, un skolai bieži vien pietrūkst iekšējo resursu, lai pārvarētu problēmas, strādātu ar viņu motivāciju un rastu labākos risinājumus.” Un, izsakot nožēlu par ierobežoto iespēju iesaistīt darbā ar problemātiskajiem jauniešiem perspektīvos jauniešus, tiek vispārinoši secināts, ka “[..] nav viegli kaut ko uzsākt bez zināšanām, informācijas un saprašanas. Tas koordinācijas deficīts mūsu izglìtojošajās un informatīvajās aktivitātēs var tikt attiecināts uz sabiedrību kopumā”, jo nav skaidrības, kura institūcija ir atbildīga, kura ir iesaistīta un kura veic specifiskās aktivitātes.

\section{Cilvēciskais faktors}

Kontekstā ar varas pārstāvju - politikas veidotāju un lēmumu pieņēmēju - cilvēciskajām, psiholog̣iskajām īpašībām, kā arī ar viņu 
vērtību orientāciju un interesēm sociālo pakalpojumu profesionāli min cilvēcisko faktoru, kas ietekmē sociālos procesus. No tā ir atkarīga jurisdikcija - likumi un daudzi sociālie procesi, tai skaitā normatīvi, kas regulē sociālos pakalpojumus. 2017. gadā notiek parlamenta vēlēšanas Vācijā, 2018. gada 6. oktobrī - Latvijā. 2017. gada 3. jūnijā Latvijā notiek pašvaldību vēlēšanas. Augstākās un vietējās varas vēlēšanas pievērš vācu un latviešu sociālo pakalpojumu sniedzēju uzmanību. "Valdības maiņa būs liels izaicinājums. Jaunie sociālie likumi tiks koriḡèti, un mēs varam vien cerēt, ka jaunais vienlīdzības likums tiks saglabāts," tā savas bažas pauž vācu speciālisti sociālās labklājības jomā.

Latvijas pārstāvji izsaka savas bažas gan emocionāli, gan racionāli: "Kaut ātrāk paietu šīs pašvaldību vēlēšanas, lai būtu redzams, kas, tas ir, kādi cilvēki, nāks pie varas," - tā tiek raksturota pirmsvēlēšanu nenoteiktības situācija. Sociālo pakalpojumu finansiālo atkarību no vietējās varas pārstāvju politiskās orientācijas un vērtîbu sistēmas cits Latvijas speciālists pēc ilglaicīgās pieredzes un novērojumiem izsaka šādiem vārdiem: "[..] personas, kas atrodas pie varas, it neko nedara ilglaicīgā perspektīvā.” Sociālo pakalpojumu speciālisti Latvijā ievērojuši vēl tādu likumsakarību: iesaistišanās sociālās dzīves norisēs ir atkarīga no vadošām varas personām.

Somu speciālistiem par personām, kas ieņem varas pozīcijas, ir savs spriedums: "Amatpersonu izglītības trūkums liedz tiem lietot tādu somu valodu, ko varētu saprast arī tie, kam somu valoda nav dzimtā valoda." Šì piezīme ir attiecināma uz gandrīz jebkuras valsts oficiālo birokrātisko un juridisko valodu un liecina par plaisu starp varas personām un parasto cilvēku. Atsvešinātība starp politiķiem un tautu ir izplatīta parādība tādēl, ka viņiem visai bieži ir zema inteliǵence, viņi neievēro ētikas normas un rīkojas savtīgi. Tas rada uzticēšanās trūkumu vai pilnīgu tās zudumu.

Cilvēciskais faktors izpaužas arī jau iztirzātajā negativitātē, kas raksturīga attieksmei pret sociāli neveiksmīgām un/vai citādām grupām. Izglìtotā, mācītā, labklājīgā sabiedrībā tā izpaužas mazāk vai arī tiek labāk apslāpēta un slēpta. Netrenētā un mazāk labklājīgā sabiedrībā negatīvā attieksme tiek pausta tieši un atklāti, tā ne mazākā mērā netiek pakļauta paškontrolei.

Cilvēciskais faktors ir attiecināms vēl uz vienu aǵentu sociālajā mijiedarbībā. Tie ir sociālo pakalpojumu galalietotāji. Viṇu domāšanas un rīcības modeḷu īpatnības ir nopietns pārbaudijums un stresa avots 
sociālo pakalpojumu sniedzējiem. Tiek minētas tādas pakalpojumu lietotāju domāšanas un rīcības modeḷu īpatnības: cilvēku ar invaliditāti pasivitāte, problemātiskās jaunatnes dạ̧as tādas uzvedības izpausmes kā alkohola un narkotisko vielu lietošana, agresivitāte, skolas neapmeklēšana, nesekmīgas atzīmes, bēgšana. Vēl vairākkārt tiek pieminēta ilgstošo bezdarbnieku un problemātiskās jaunatnes zemā pašcieņa, kas viṇiem savu dzīves situāciju kavē mainīt pret labāku.

\section{Secinājumi}

\section{Secinājumi par barjerām un šḳēršliem sociālo pakalpojumu organizāciju darbā}

Vispārinot 2017. gada papildpētījumā par barjerām un šḳēešlı̣iem iegūtās informācijas saturu, īsumā ir secināms, ka tika iegūta padzilināta un paplašināta informācija par barjerām un šķēršlı̧iem sociālo pakalpojumu organizāciju darbā, otrkārt, apstiprinājās informācija, ko partneri bija snieguši pirms gada, treškārt, vienam gadam paejot, pārmaiņas netika uzrādītas.

Materiālie šḳēešsli kopumā nav nedz skaitliski lielākie, nedz nozīmīgākie šķērṣ̌li. Izṇēmums ir sabiedriskā transporta pieejamība laukos. Tiek minēti trīs materiālie šḳēršlı: nauda, telpas un sabiedriskais transports.

1. Nauda/finanses. Par finanšu nepietiekamību vai par to, ka pēdējā laikā finanses tiek samazinātas sociāliem pakalpojumiem, bažas izteikuši vācu un somu pakalpojumu sniedzēji.

Naudas ierobežojums personālam parādās norādēs par tā zemo atalgojuma limeni.

2. Telpas. Par to, ka jauniešiem trūkst telpu, kur varētu pulcēties, žēlojas poḷu partneris, par imigrantu un vietējo iedzīvotāju kopīgās pulcēšanās telpu trūkumu runā zviedru partneri. Telpu stāvokḷa uzlabošana ir aktualitāte, ko min Latvijas partneri no Vidzemes.

3. Sabiedriskā transporta pieejamības ierobežojumi reǵionu lauku dzīves vidē ir visbiežāk minētais materiālais škēerslis. Tos ir nosaukuši visu dalībvalstu partneri, izṇēmums ir Zviedrija. Latvijā sabiedriskā transporta pieejamība laukos kḷūst aizvien ierobežotāka, kopš 2009. gadā tika konsolidēts budžets jeb drastiski taupits uz 
sociālo pakalpojumu finansēšanas samazināšanas un darba ņēmēju algu samazināšanas rēḳina, lai, pārvarot finanšu spekulantu izraisīto ekonomisko krīzi, glābtu no bankrota privātu banku par nodokḷu naudu un pasargātu no zaudējumiem visbagātāko sociālo slāni.

\section{Nemateriālas barjeras un šķēršlı li}

Biežāk minētas ir nemateriālas iedabas barjeras un šķēešsli. Tie ir juridiski, darba organizatoriskie un sociālās un individuālās psihologíjas jautājumi. Psiholoǵiskā problemātika ir aktuāla abām pusēm - pakalpojumu sniedzējiem un saņēmējiem.

Juridiskie šḳēršlı. Tie ir atškirīigi atkarībā no pakalpojumu lietotāju kategorijām un valstu specifikas. Juridiskie šḳēešlı rodas trīs iemeslu dēḷ. Tie ir: likumdošanas mainī̌sana, likumu trūkums un juridisko normu harmonizācijas līmenis. Tā Dānijā sociālo pakalpojumu sniegšanu bēg̣̣iem kavē saskaņota likumdošanas kopuma trūkums. Somijā pakalpojumu sniegšanas (bēg̣̣iem un imigrantiem) juridiskās regulācijas reformas situāciju padara kritisku. Likumdošanas mainīšana nozīmē nenoteiktību, kas mulsina un kavē pārliecinošu rīcību. Pārejā no integrācijas pakalpojumiem uz vispārējiem pakalpojumiem somu speciālistu novērtējumā "viṇi (bēg̣̦i - A. S.) bieži iekrìt kā aizā". Latvijā 2017. gada pirmajā pusē speciālisti pauda neapmierinātību par sociālās uzṇēmējdarbības likumiskās regulācijas neesamību. 2017. gada oktobrī Sociālā uzṇēmuma likums tika pieņemts, un 2018. gada aprīlī tas ir stājies spēkā. Latvijā aktualizētā deinstitucionalizācijas programma normatīvā regulējuma trūkuma dẹl speciālistiem ir radījusi nenoteiktỉbas izraisìtu stresu.

Pakalpojumu sniedzēju psiholog̣iskās problēmas ir izvairǐ̌anās no refleksijas par pārmain̦ām, izdegšanas sindroms, negatīvo emociju, ko izjūt pakalpojumu lietotāji, pārstrādāšana, pakalpojumu saṇēmēju valodas nezināšana.

Bez psihologiskās problemātikas jāmin arī speciālistu norādītās reizēm sastopamās subjektīvās atškiriribas starp sociālo pakalpojumu sniedzējiem un saṇēmējiem vajadzību izvērtēšanā. Abu pušu uzskati un priekšstati par pakalpojumu lietotāju vajadzībām mēdz stipri atškịties.

Multikulturālā sabiedrība un komunikācija rada virkni savstarpējās saprašanās barjeru. Tās ir valodas, ieradumu, paražu, uzvedības normu atšķirības. 
Pakalpojumu lietotāju psihologiskās problēmas, ko novērojoši speciālisti, ir demotivācija pārmaiņām, tradicionāls lomu modelis, bailes, bēglu un imigrantu izvairīgās atbildes par dzivesvietu kā šķērsli viņu ātrākai integrācijai, bēgḷu un imigrantu psihologiskās traumas, kuras izraisījusi kara pieredze.

Pakalpojumu saṇēmēju zemais izglìtības līmenis sasaistās ar sociālo prasmju un situāciju risināšanas prasmju trūkumu.

Valodas barjeras tiek minētas kā šḳērslis un barjera tiem partneriem Dānijā, Somijā, Vācijā un Zviedrijā, kuri sniedz pakalpojumus bēgliem un imigrantiem. Pastāv abpusējas valodas barjeras, jo imigrantiem ir nepietiekamas vietējās valodas zināšanas, pakalpojumu sniedzējiem nav imigrantu valodu zināšanas. Tulki ne vienmēr ir pieejami, un tulku algošanai organizācijām jo bieži nav naudas.

Kultūru atškirības, kas izpaužas uzvedības normās un paražās, izraisa nesaprašanos starp pakalpojumu saṇēmējiem un sniedzējiem darbā ar bēgliem un imigrantiem.

Dezintegrācija sabiedrībā ir izplatìta parādība, un tā izpaužas pēc daudzām identitātes pazīmēm: pilsonības, etniskās piederības, piederības pie noteiktas vecumgrupas un starppaaudžu attiecībās. Igauṇu partneri atzīst, ka kopumā sabiedrībā vērojama sirsnīgas, draudzīgas kopdzives jeb konvivialitātes mazspēja, deficīts un nepratîba.

Komunikācija, darbu koordinācija un informācijas aprite ir visai nozīmīgs organizatoriskā rakstura barjeru kopums, kuru cēlonis ir menedžmenta atslābināts darba režìms. Šī problemātika tiek konstatēta starp viena līmeṇa sociālo pakalpojumu organizācijām un starp subordinētām augstākstāvošām un tām pakḷautām zemākstāvošām institūcijām.

Noslēgumā vispārīgi secinājumi par spēcināšanas vietu sociālekonomiskā konteksta galvenajiem informācijas blokiem.

\section{Vispārīgi secinājumi par statistiskiem datiem}

Statistiskie dati par pirktspējas standartu, apdzìvotības blīvumu un iedzìvotāju sastāva pārmaiņām partnerības vietās ir stipri atškirīịi. Tam visam ir logisks, sociāls, ekonomisks un uz fizikālo apstākḷu savdabību balstīts izskaidrojums.

Apdzīvotības blīvums un pārmaiņas iedzīvotāju sastāvā ir savstarpēji saistìti rādītāji. Pamatcēloṇi zemam apdzīvotības blīvumam 
un novecošanai kā raksturīgākai pazīmei iedzìvotāju sastāva pārmaiņās līdzās depopulācijai ir skaudri klimatiskie vai skarbi sociālie un ekonomiskie dzīves apstākḷi. Zviedrijas un Somijas ziemeḷos skaudrais klimats, ko ietekmē šo valstu geogrāfiskais stāvoklis, nav pievilcīgs dzīvošanai, bet šajās valstīs to daḷēji kompensē labvēlīgie ekonomiskie rādītāji, kas vismaz uz kādu laiku cilvēkus piesaista šai vietai un notur. Cēlonis tam, ka klimatiski labvēlīgākos apstākḷlos Latvijā iedzīvotāju blīvums ir tikpat zems kā tajās Somijas vietās, kas atrodas daudz tālāk uz ziemel̦iem, ir Latvijas lauku apdzīvoto vietu nelabvēlīgie sociālie un ekonomiskie dzìves apstākḷi - darbavietu trūkums, smags darbs, zems atalgojums, nabadzība, sociālo, medicīnas un kultūras pakalpojumu pieejamības ierobežojumi -, tāpēc lauku iedzīvotāji aizbrauc uz pilsētām. Liels skaits Baltijas valstu iedzīvotāju kā ekonomiski bēg̣̣i dodas arī uz ārzemēm. Ekonomiski aktīvie darbspējas vecuma pieaugušie un jaunieši aizbrauc no laukiem, jo pilsētās paveras iespēja iegūt augstāku izglìtību un atrast darbu. Šis process uzskatāmi ir izpaudies Baltijas valstu pārejas sabiedrībās.

Urbanizācijas tendence kā joprojām notiekošs process arī ir ņemama vērā. Tā vēl arvien turpinās, jo pilsētvide piedāvā daudz vairāk iespēju salīdzinājumā ar lauku dzīves vidi un citu dzīves stilu. Urbanizācija ir viens no iemesliem, kāpēc laukos iedzīvotāju kḷūst mazāk un palielinās vecāka gadagājuma cilvēku īpatsvars.

Vispārīgās ar iedzīvotājiem saistītās dominējošās attīstības tendences lauku dzīves vidē ir izsakāmas ar diviem terminiem: depopulācija un populācijas novecošana.

Iedzīvotāju skaita pieaugums SEMPRE projekta īstenošanas vietās Somijā, Dānijā un Zviedrijā (tās klimatiski skaudrā reg̣ionā) ir hipotētiski izskaidrojams ar imigrācijas plūsmu virzīšanu uz šiem reǵioniem no citu kontinentu valstīm, kas ir ekonomiski izpostītas ilgstošo sociālo konfliktu rezultātā, un no bijušās PSRS valstīm.

\section{Vispārīgi secinājumi par vietu īpatnībām}

Informācija, kas norādīta respondentu atbildēs uz jautājumu par vietu īpatnībām, liecina par šādām vietu ekonomiskām īpatnībām un atškiirībām: Vācijas partneris no Plēnes norāda, ka lauksaimniecībai raksturīga sezonāla nodarbinātība. Baltijas valstīm raksturīgs rādītājs ir augsts bezdarba līmenis, ekonomiskā depresija un cilvēku depresija. 
Salīdzinājumam l̦oti zems bezdarba līmenis un zems nodarbinātības līmenis privātā sektorā tiek norādīts saṇemtajās ziṇās par Dāniju.

Atbildēs par vietu īpatnībām ir minētas migrācijas plūsmas. Tās notiek divos pretējos virzienos - migrējot no laukiem uz pilsētām un emigrējot uz ārzemēm (tas ir izplatīts process Baltijas valstīs). Sociāli un ekonomiski labklājīgās Skandināvijas valstis un Vācija ir atraktīvs imigrācijas galamērḳis.

Cita zīmīga vietu ìpatnība, kas norādīta atbildēs, ir saistīta ar infrastruktūras kvalitāti un stāvokli. Baltijas valstīs daudzviet ir ierobežota izglìtības, veselības aprūpes, pasta, banku, veikalu pakalpojumu pieejamība. Un pagaidām sociālo pakalpojumu pieejamība reǵionos turpina pasliktināties.

Zviedrijā Norbotenas lēnes īpatnība ir izteikts profesionāḷu trūkums sociālajā jomā un medicīnā.

Sabiedriskā transporta pakalpojumi ir problemātiski daudzviet. Projekta vietās Dānijā autoceḷu tîkla kvalitāte tiek raksturota kā laba, bet sabiedriskā transporta pieejamība ir tāda, ka mobilitāte bez personiskā auto ir stipri apgrūtināta vai pat neiespējama. Lìdzịgi ir Vācijā Plēnē un Ziemeḷfrīzlandē.

Latvijas reǵionos lauku dzīves vidē mazinās sabiedriskā transporta pieejamība un autoceḷu stāvoklis daudzviet ir kritisks.

\section{Vispārīgi secinājumi par faktoriem, kas ietekmē sociālo pakalpojumu galalietotāju dzīves apstākḷus}

Sociālo pakalpojumu galalietotāju dzīves apstākḷu raksturojums liek secināt, ka šie cilvēki vairāk vai mazāk atrodas diskomforta zonā. Galvenie faktori, kas ietekmē viṇu dzives apstākḷus, ir bezdarbs, mobilitātes ierobežojumi sabiedriskā transporta nepieejamības dēl un sava auto neesamība naudas trūkuma, veselíbas stāvokḷa vai citu iemeslu dēḷ. Neapšaubāms fakts ir sabiedrības dezintegrācija pēc sociālās stratifikācijas nabagos un bagātos, pēc piederības pie citas rases, etnosa, pēc tādām atšķirībām kā invaliditāte, devianta uzvedỉba. Sociālā dezintegrācija izpaužas daudzējādi, arī kā telpiskā segregācija - sociāli līdzīgie ierobežo un norobežo savu dzīves, darba un komunikācijas telpu.

Psihologískās problēmas ir izplatīts un būtisks faktors, kas ietekmē šo cilvēku dzìvi. Viṇiem tiek piedēvētas šādas psiholoǵiskās ìpašības un stāvokḷi: nenoteiktības un neziņas radīts diskomforts, 
dažādu vardarbỉbas veidu izraisìta psihologiska trauma, bezcerība, apātija, motivācijas trūkums, sociālo prasmju deficīts, neprasme tikt galā ar dažādām dzīves situācijām. Vientulība tiek pieminēta saistībā ar vecāka gadagājuma personām Somijā un personām ar invaliditāti Latvijā.

\section{Vispārīgi secinājumi par barjerām un šḳēršliem sociālo pakalpojumu sniedzēju darbā}

Barjeras un šḳēršlli sociālo pakalpojumu organizāciju darbā izpaužas kā daudzveidīgi apgrūtinājumi un problemātika. Atškşirības determinē valstu atšḳirības un daudzveidīgo pakalpojumu lietotāju kategoriju atšķirības. Darbā ar katru pakalpojumu lietotāju kategoriju ir sava darba specifika. Tādēḷ veiksmīgāku darbu un tā rezultātu nodrošina sociālo pakalpojumu sniedzēju specializācija.

Iegūtā informācija liecina, ka kopumā materiālie šḳēršli pakalpojumu sniegšanā nav galvenie. Par finanšu nepietiekamību kā šķērsli pakalpojumu sniegšanā izsakās tie somu un vācu sociālo pakalpojumu sniedzēji, kas strādā ar bēg̣̣iem un imigrantiem. Vairāk naudas būtu vajadzīgs valodu kursiem un tulku atalgošanai. Taču Baltijas jūras regionā ir valstis, kur sociālo pakalpojumu organizāciju personāls tiek atalgots neadekvāti zemu.

Neapmierina arī sabiedriskā transporta pieejamības ierobežojumi reǵionu lauku dzīves vidē. Tas ir visbiežāk minētais materiālais šķērslis. Sabiedriskā transporta pieejamība ir akūta problēma, kurai ir jāmeklē risinājumi.

Padziḷinātajā barjeru un šḳēršlu apzināšanā respondentu atbildes atklāja daudz plašāku problēmu klāstu, konkretizējot vairāku problēmu saturu. Atbildēs tika sniegts daudz plašāks psihologisko problēmu izklāsts, kā arī ziṇas par iepriekš neminētu būtisku problemātiku, kas ietekmē darbu. Tā ietver, piemēram, societālas barjeras, kas faktiski ir sociālās psihologijas izpausme visas sabiedrības mērogā, komunikāciju, darbu, rīcības, informācijas aprites koordinācijas kvalitāti, kas būtu uzlabojama, pie varas esošo personu īpašỉbu, vērtību, interešu un lēmumu ietekme uz sociāliem procesiem un sociālo pakalpojumu sniegšanu.

Societālas barjeras šajā projektā izpaužas kā dažāda negatīva attieksme pret atšķirībām, citādību, svešîbu. Tā ir izskaidrojama ar 
izdzīvošanas instinktu un psihes dzīlēs mìtošām bailēm. Bezapzinīga un reizēm reāla apdraudējuma izjūta izraisa negativitāti pret jebkuru svešinieku.

Psihologiskās problēmas skar sociālo pakalpojumu organizāciju profesionāḷus visai dziḷi, jo darbs ar pakalpojumu lietotājiem noris patstāvīga, paaugstināta stresa apstākḷos. Gadījumu analīze, situāciju risināšana un komunikācijas stils rada distresu un hiperstresu.

Komunikācija un koordinācija ir nozīmīgi faktori, kuri ietekmē darbu un par kuriem sniegts daudz kritisku ziṇu. Tās abas tiek raksturotas kā neapmierinošas un apgrūtina ikdienas darbu. Komunikācijā sarežğijumiem ir vairākas dimensijas. Rodas sarežğijumi komunikācijā ar kolēgiem, vadību un pakalpojumu lietotājiem.

Darba, rīcības koordinācijas un informācijas apmaiņas operativitātes nepietiekamība ir būtiskākās nepilnības subordinētajā komunikācijā starp augstāk un zemāk stāvošām sociālās labklājības institūcijām.

Informācijas aprites operativitātes, komunikācijas un koordinācijas kvalitātes uzlabošana tiek aktualizēta kā neatliekama nepieciešamìba.

\section{leteikumi}

1. Pieṇemot lēmumu par infrastruktūras objektu likvidāciju lauku apdzivotās vietās, pamatoties uz ilglaicīgu stratēgisku perspektīvu, nevis uz konkrētā brīža ekonomisko izdevīgumu - naudas izdevumiem. Ja infrastruktūras konsolidācija ir vienīgais risinājums, tad piedāvāt alternatīvas. Gudra, atbildīga un laba pārvaldība lēmumu pieņemšanā nozīmē ilglaicīgu stratēǵiju un apsvērumu, ka pastāv vērtības, kas naudā nav samaksājamas un izsakāmas.

2. Lauku apdzīvoto vietu paglābšana no iztukšošanās un izzušanas no Latvijas kartes ir saistìta ar ekonomiskās aktivitātes iedzīvināšanu, ražotņu izveidošanu un sociālo pakalpojumu pieejamības nodrošināšanu. Daži mēgeinājumi tās radīt Latvijā beigušies nesekmīgi, jo vietējie iedzīvotāji tiek ietekmēti - viṇiem tiek iestāstīts, ka ražotņu izveidei ir jāpretojas, jo ražošana piesārṇošot vidi. Ja valsts un vietējās pašvaldības ir gudras un atbildīgas, tad 
ražošanas izraisītā vides piesārṇošana kontrolēti var tikt reducēta lìdz minimumam.

3. Mobilo sociālo pakalpojumu piegāde un nodrošināšana aprūpei mājās vecāka gadagājuma personām un personām ar invaliditāti ir viens no risinājumiem vietās, kur sociālo pakalpojumu infrastruktūra likvidēta vai izzudusi, ja viņi lauku dzives vidē dzīvo vieni un šai vidē nenotiek nekādas pozitīvas pārmaiņas. Mobilie sociālie pakalpojumi daudzviet sevi apliecinājuši kā labu praksi. Latvijā mobilo sociālo pakalpojumu piegādi un aprūpi mājās piedāvā Latvijas Samariešu apvienība. Šādam pakalpojumu tỉklam būtu jāpārklāj visa Latvijas teritorija. Pašvaldību sociālie dienesti būtu tie aǵenti, kas organizē mobilo sociālo pakalpojumu pieejamību tiem, kam tie ir vajadzīgi. Maksāt par pakalpojumiem varētu gan paši to lietotāji, gan pašvaldỉba, ja to lietotāji nav maksātspējīgi.

4. Sabiedriskā transporta pieejamības jautājums ir risināms, racionāli veidojot transporta kursēšanas grafiku, šo pakalpojumu subsidējot no nodokḷu ieñēmumiem un meklējot inovatīvus risinājumus transporta pakalpojumiem laukos. Te varētu izpausties iedzìvotāju pašiniciatīva kā labas kopā dzīvošanas spēja vai vietējās pašvaldības organizēts transporta pakalpojums, apspriešanās rezultātā izlemjot, kad un kur notiks braucieni, lai apmierinātu sadzìviskās vajadzības. Transporta problemātika laukos ir l̦oti aktuāla, tāpēc tās risinājumi pašlaik tiek meklēti arī kādā Eiropas Savienības Interreg programmas Baltijas jūras regiona valstu projektā, kurā ir iesaistìta arī Latvija.

5. Atkārtoti izskatīt valsts pārvaldības decentralizācijas principa piemērošanu. Funkcijām adekvātu valsts pārvaldības institūciju pārvietošana no Rīgas uz reǵioniem veicinātu vietējo saimniecisko darbību un nodarbinātību vismaz servisu jomā.

6. Aktuāls uzdevums ir sociālo pakalpojumu sniedzēju profesijas prestiža celšana. Svarīgs nosacījums tam ir atalgojuma kāpinājums, izvērtējot šì darba augsto spriedzes līmeni un nozìmi sociālā miera uzturēšanā. Tāpat personāls ir preventivi aizsargājams no psiholog̣iskās izdegšanas gan racionālā darba laika organizēšanā, gan darba veidu sadalīšanā, tos dažādojot.

7. Sociālo pakalpojumu organizāciju menedžmenta darbs ir nopietni pilnveidojams. Vadī̌̌anas funkcijas ir uzlabojamas, jo bieži 
ir pausta personāla neapmierinātība ar komunikācijas, aktivitāšu koordinācijas, kā arī informācijas aprites kvalitāti. Informācijas apmaiṇas operativitāte, aktivitāšu koordinācija, augstāk stāvošo institūciju komunikācija ar zemāk stāvošām institūcijām ir funkcijas, kuru kvalitāte ir atkarīga no vadības. Koordinācijas funkcija prasa vadīšanas personāla sasprindzinājumu. Lai šo funkciju labi veiktu, ir vajadzīga griba, pienākuma un atbildības apziṇa. Te ir plašs darba un nepieciešamo uzlabojumu lauks.

8. Aktuāls uzdevums izglītības institūcijās un darbavietās ir turpināt mainīt cilvēku domāšanas un uzvedības modeḷus. Šì nepieciešamìba ir jūtama saistîbā ar plašo psiholoǵisko problēmu izplatîbu un cilvēciskā faktora lomu un nozīmi dažādos sociālos slāņos un grupās - gan sabiedrības pārvaldỉbas līmenī, gan sabiedrības attieksmēs, domāšanas veidā un uzvedībā. Pašreizējais sociālo pakalpojumu lietotāju un dậeji pakalpojumu sniedzēju situācija, kā arī atmosfēra sabiedrībā liecina par pārmaiṇu nepieciešamību.

Noslēgumā kā labas prakses piemērs sniegta zviedru partneru pieeja migrantu jautājuma risināšanai reti apdzīvotā Norbotenas lēnē Zviedrijas ziemel̦os:

Nozīmīgs aspekts mūsu projektā ir tas, ka pieaugošā migrācija uz Norbotenu rezultēsies jaunu pakalpojumu izveidošanā, kas uzlabos vispārējo labklājību un izaugsmi. Piemēram, tulku, dzimtās valodas skolotāju, jaunas ārzemju virtuves un pārtikas piegādes pakalpojumi, kā arī pakalpojumi citās valodās, nevis zviedru valodā un vèl kas cits. Droši, ka büs vēl kas vairāk.

Šì pieeja ir paraugs un piemērs tam, kā var pārdomāt jebkuru problemātisku situāciju un meklēt tai risinājumu, lai uzlabotu kopējos dzives apstākḷus.

\section{Atsauces}

Bela, B., N̦ikišins, J. (2018) Ilgtspējas sociālā dimensija: vai virzāmies pretī labklājībai un cieṇpilnai dzīvei? Grām.: Bela, B. (zin. red.) Ilgtspējīga attīstība un sociālās inovācijas. Rīga: LU Akadēmiskais apgāds, 108.-139. lpp.

Dzenovska, D. (2012) Aizbraukšana un tukšums Latvijas laukos: starp zudušām un iespējamām nākotnēm. Rìga: Biznesa augstskola Turība, 198 lpp. 
Eurostat. Statistical data on: 1. PPS/capita in \% of EU (2013), 2. Population density (2013) and 3. Relative Population change 2011-2015. Available: http:// ec.europa.eu/eurostat/web/regions/data/database_[accessed: July 20, 2016].

Hazans, M. (2011) The Changing Face of Latvian Emigration, 2000-2010. In: Latvia. Human Development Report 2010/2011. National Identity, Mobility and Capability. Riga: ASPRI, pp. 77-101.

Latvija. Pārskats par tautas attīstību 2010/2011. Nacionālā identitāte, mobilitāte, rīcībspēja (2012) Rīga: Latvijas Universitāte, 153 lpp.

LR1. Sociālās aprūpes centru darbinieki piesaka badastreiku. Dienas ziņas 19.09.2018. Pieejams: www.lsm.lv [skatīts 20.09.2018.].

Simmel, G. (1992) Soziologie. Untersuchungen über die Formen der Vergesellschaftung. In: Georg Simmel Gesamtausgabe (GSG). Bd. 11. Frankfurt am Main: Suhrkamp, S. 764-771.

Simmel, G. Stranger. Available: http://www.wattis.org/MEDIA/00413.pdf [accessed: December 12, 2015].

Simon, M., Mikesova, R. (2014) Population Development and Policy in Shrinking Regions: the Case of Central Europe. Prague: Institute of Sociology, Academy of Sciences of Czech Republic, $132 \mathrm{p}$.

Towards a Convivial Economy. The Contribution of a Re-formed Community Diakonia in Europe (2017) Geneva: The Lutheran World Federation, 54 p. 
